Wilfrid Laurier University

Scholars Commons @ Laurier

7-2007

\title{
Mary Magdalene Preaches through Song: Feminine Expression in the Shrewsbury Officium Resurrectionis and in Easter Dramas from the German Lands and Bohemia
}

\author{
Peter V. Loewen \\ Rice University \\ Robin Waugh \\ Wilfrid Laurier University, rwaugh@wlu.ca
}

Follow this and additional works at: https://scholars.wlu.ca/engl_faculty

\section{Recommended Citation}

Loewen, Peter V. and Waugh, Robin, "Mary Magdalene Preaches through Song: Feminine Expression in the Shrewsbury Officium Resurrectionis and in Easter Dramas from the German Lands and Bohemia" (2007). English and Film Studies Faculty Publications. 1.

https://scholars.wlu.ca/engl_faculty/1

This Article is brought to you for free and open access by the English and Film Studies at Scholars Commons @ Laurier. It has been accepted for inclusion in English and Film Studies Faculty Publications by an authorized administrator of Scholars Commons @ Laurier. For more information, please contact scholarscommons@wlu.ca. 


\title{
Mary Magdalene Preaches through Song: Feminine Expression in the Shrewsbury Officium Resurrectionis and in Easter Dramas from the German Lands and Bohemia
}

\author{
By Peter V. Loewen and Robin Waugh
}

To observe that Mary Magdalene, in her role as "apostle to the apostles," transcends the limits of human expression is to say nothing new; many versions of the Easter story attest to her transformative role. ${ }^{1}$ What is surprising is the ability of a relatively neglected group of texts, known collectively as the Shrewsbury Fragments, to demonstrate just how transformative her mode of expression can be. The combination of Latin and English verses that make up the Shrewsbury Fragments is, according to their modern editor, Norman Davis, unknown in any other text of English provenance. ${ }^{2}$ Critical interest in these works has been largely limited to source hunting and attempts to establish a date for them because, doubtless, of what they are: tantalizing excerpts from an Officium pastorum, an Officium Resurrectionis, and an Officium peregrinorum on folios $38 \mathrm{r}-42 \mathrm{v}$ of a fifteenthcentury paper manuscript, Shrewsbury School MS VI (formerly Mus.III.42). ${ }^{3}$ W. W. Skeat brought these plays to public attention in 1890 and noted correspondences between them and the Shepherds play (number 15) of the York cycle. He seems to have started the speculations about them. ${ }^{4}$ The result has been several

Portions of this article were presented in a paper for the session "The Uses of Music in Early Drama," sponsored by the Medieval and Renaissance Drama Society, at the International Medieval Congress, Leeds, July $12-15,2004$. We would like to thank the participants for their comments, particularly Richard Rastall, the respondent for the session. We would also like to thank the anonymous reviewers for Speculum. Robin Waugh would like to thank Wilfrid Laurier University and its institutional grant from the Social Sciences and Humanities Research Council of Canada for supporting the trip to Leeds to present the paper. Finally, we would like to thank Prof. L. A. Desmond for first inspiring our interest in medieval studies.

\footnotetext{
${ }^{1}$ See Ann Graham Brock, Mary Magdalene, the First Apostle: The Struggle for Authority, Harvard Theological Studies 51 (Cambridge, Mass., 2003), pp. 9-18, 161-75, and n. 35.

${ }^{2}$ Norman Davis, ed., Non-Cycle Plays and Fragments, Early English Text Society, S.S., 1 (London, 1970), p. xix. See pp. 1-7 for his text of the Shrewsbury Fragments, which is the edition we use.

${ }^{3}$ See Davis for the textual history, the manuscript context, and the dialects of these works (pp. xivxxii).

${ }^{4}$ See W. W. Skeat, "Fragments of Yorkshire Mysteries," The Academy (January 11, 1890), pp. 2728. See also his entries in the same journal for January 4, 1890, pp. 10-11, and lines 120-29 of York 15. The other two plays in Shrewsbury do not directly correspond with their counterparts in the York cycle. Individual pageants in the English cycle plays will be referred to by cycle title (conventionally abbreviated to one word, e.g., York), play number, and line number(s). The editions are The York Plays, ed. Richard Beadle (London, 1982); The Towneley Plays, ed. Martin Stevens and A. C. Cawley, Early English Text Society, S.S., 13-14 (Oxford, 1994); The N-Town Play: Cotton MS Vespasian D.8, ed. Stephen Spector, Early English Text Society, S.S., 11-12 (London, 1991); and The Chester Mystery Cycle, ed. R. M. Lumiansky and David Mills, Early English Text Society, S.S., 3 and 9 (London, 1974
} 
editions and some criticism of the Shrewsbury texts from, for instance, Hardin Craig, Norman Davis, Frank Harrison, and Karl Young and criticism of the music from, for instance, Susan Rankin and Richard Rastall. Many of these writers see the Shrewsbury Fragments as significant because they appear to come from much earlier than their manuscript date, perhaps from as early as the twelfth century. ${ }^{5}$ These works would seem to be mainly useful, then, for trying to establish a chronology for the development of drama in England. The scholars who suggest an early date typically point to the cathedral statutes of Hugh of Nonant, bishop of Lichfield from 1188 to 1198 , which describe liturgical dramas that seem to be identical to the ones represented in Shrewsbury School MS VI. This apparent correspondence raises the possibility that the Shrewsbury plays were performed at Lichfield and perhaps written there, and Rankin proposes that the existing texts are a triplum part book for a vicar choral at Lichfield Cathedral. This provenance is certainly plausible. ${ }^{6}$ The manuscript contains only the parts for the actor who plays Mary Magdalene, thus the epithet "Fragments" for the Shrewsbury works.

Much work needs to be done in investigating the spiritual functions of these plays, in identifying the musical forms that they include, and in analyzing the transformative roles of Mary Magdalene and the other female characters in them. ${ }^{7}$ This program of study seems impractical on the basis of the existing documents and scholarship. The plays from Shrewsbury are incomplete and cannot be sufficiently reconstructed using the dramas with which scholars have traditionally compared them. These so far have proven to be either Latin ones or English onesnever a combination of the two. Scholars have noted connections between the Shrewsbury Fragments and a small number of plays from France and the German lands, but connections to dramas from central and eastern Europe have yet to be fully explored. ${ }^{8}$

and 1986). The Shrewsbury Fragments appear to be liturgical dramas, so they would likely differ in performance practice from the cycle dramas.

${ }^{5}$ See V. A. Kolve, The Play Called Corpus Christi (Stanford, Calif., 1966), p. 34; cf. Rosemary Woolf, The English Mystery Plays (Berkeley, Calif., 1972), pp. 327 and 331.

"Susan Rankin, "Shrewsbury Manuscript VI: A Medieval Part Book?" Proceedings of the Royal Musical Association 102 (1976), 129-44. See also Statutes of Lincoln Cathedral, ed. Henry Bradshaw and C. Wordsworth, 2 pts. in 3 vols. (Cambridge, Eng., 1892-97), 2:15 and 23.

7 Unfortunately, we would have to admit that the most profound concerns that readers are likely to maintain about the Shrewsbury Fragments, such as, Why do they have a unique pattern of switching back and forth between Latin and the vernacular? What is the significance of their preservation in a fifteenth-century manuscript? To what kind of tradition of performance in late-medieval England do they point? receive precious little in the way of relief as a result of our arguments. We would only submit that the content of the extant passages shows a remarkable thematic unity. Each character for whom substantial parts are preserved, III Pastor, Tertia Maria, and Cleophas, is visited by angels or by Jesus himself and then declares faith in this supernatural visitation, even in the face of actual or implied opposition. See Officium pastorum, lines 14-17; Officium Resurrectionis, lines 31-32; and Officium peregrinorum, lines 72-73. Proclamation of joyful news and the use of song are also important correspondences among the three characters: Officium pastorum, lines 31-33 and 36-37; Officium Resurrectionis, lines 30-44; Officium peregrinorum, lines 40-41 and 67-70. Perhaps, then, the Shrewsbury Fragments record the parts of an actor who was considered suitable for a particular kind of role.

${ }^{8}$ The combination of the Latin, English, German, and Czech languages in our study might well make a reader think of the marriage of Anne of Bohemia to Richard II of England in January of 1382 
The Officium Resurrectionis from Shrewsbury exhibits connections to the long tradition of Visitatio sepulchri ceremonies. Examinations of the Visitatio sepulchri by Helmut de Boor and David Bjork, who concentrate on the texts, and Rankin and Michael Norton, who concentrate on the music, have shown that such plays exhibit patterns of regional development rather than a general process of evolution from simpler to more complex forms.9 This approach opens the way to a method of analysis that compares the various regional traditions with one another and examines the relationship between their Latin and vernacular passages. One finds then that plays from the German lands and Bohemia preserve Latin lyrics in a similar way to the Shrewsbury texts. Moreover, the English, German, and Bohemian plays also incorporate the same program of vernacular exegeses, which typically involve preaching by Mary Magdalene. This fact broadens Rankin's observation that "despite the profound alterations" that occur in the European Easter drama in general, including the incorporation of new vernacular material, the repertory maintained its basic shape and developed its didactic principles along parallel lines. ${ }^{10}$

By focusing on the words, music, and preaching of Mary Magdalene in Easter plays from Shrewsbury, Trier, Füssen, and Prague, we shall prove that these dramas are related. This connection sheds much light on the musical form and the program of vernacular exegesis that appear in the English drama and demonstrates that the Shrewsbury Officium Resurrectionis is not an isolated English relic. It is instead part of a larger European phenomenon, hitherto unrecognized in medieval religious drama-one that relies on the rhetorical voice of music. This musical rhetoric exhibits a consciously feminized mode of expression that borders on overtly "profeminine" attitudes (to use Alcuin Blamires's term) and even hints at a new language exclusive to women. ${ }^{11}$

(we acknowledge an anonymous reviewer who indicated this possible connection). For the occasion Anne brought servants and chaplains with her. See Nigel Saul, Richard II (New Haven, Conn., 1997), pp. 85-95 and 455-57. Direct connections between British, German, and Czech drama c. 1382 are, therefore, possible. See Andrew Taylor, "Anne of Bohemia and the Making of Chaucer," Studies in the Age of Chaucer 19 (1997), 95-119. Most tantalizing for our purposes is a "passage in which Wycliffe claims that Anne could have owned the four gospels in Latin, Bohemian (i.e., Czech), and German" (ibid., pp. 103-4 and n. 30, 105-6, and 109); see Rudolf Buddensieg, ed., John Wiclif's Polemical Works in Latin, 2 vols. (London, 1883), 1:168. Anne even had a connection with Shrewsbury. An illumination in a charter depicts her interceding on behalf of that town's people. See Saul, Richard II, plate 15. Comparative studies of English and Czech medieval dramas are rare, but see Jarmila F. Veltruský, A Sacred Farce from Medieval Bohemia: Mastičkár̆, Michigan Studies in the Humanities 6 (Ann Arbor, Mich., 1985).

${ }^{9}$ Helmut de Boor, Die Textgeschichte der lateinischen Osterfeiern, Hermaea, n.s., 22 (Tübingen, 1967); David A. Bjork, "On the Dissemination of Quem quaeritis and the Vistatio sepulchri and the Chronology of Their Early Sources," Comparative Drama 14 (1980), 46-69; Susan Rankin, "The Mary Magdalene Scene in the Visitatio sepulchri Ceremonies," Early Music History 1 (1981), 22755; Michael Norton, "On 'Stages' and 'Types' in Visitatio sepulchri (Part I)," Comparative Drama 21 (1987), 34-61.

${ }^{10}$ Rankin, "The Mary Magdalene Scene," pp. 228-29.

${ }^{11}$ Alcuin Blamires, The Case for Women in Medieval Culture (Oxford, 1997), p. 171. 


\section{Sources for the Shrewsbury OfFicium Resurrectionis: THE EASTER STORY}

The subject matter of the Shrewsbury Officium Resurrectionis derives from the Gospel of Mark (16.1-8) and concerns the visit of the three Marys-Mary of Jacob, Mary of Solomon, and Mary Magdalene-to the Holy Sepulcher on Easter morning. In this play they are identified as Prima Maria, Secunda Maria, and Tertia Maria. ${ }^{12}$ The Officium Resurrectionis includes (presumably) all of the lines for Tertia Maria and for the ensemble of all three women. It also contains fragments of lines for Prima and Secunda Maria, just a word or two in each case, which seem to be cues for the actor playing the part of the Third Mary (Mary Magdalene). The Latin materials in the drama- "Heu! Redemcio Israel" (see the Appendix, below, 1.a, 1.c, and 1.e), "Heu! cur ligno," "Iam iam, ecce" (Appendix, 3.a), "O Deus, quis reuoluet nobis lapidem" (Appendix, 3.b-e), and "Surrexit Christus, spes nostra" - come from sources associated with the widely disseminated liturgical Easter ceremonies.

The development of Easter ceremonies to the time of the Shrewsbury Fragments is difficult to trace, in part because of the variant traditions that medieval dramatists could draw upon when composing Easter dramas. For example, the role of Mary Magdalene in a Resurrection play could be construed in a number of ways. Choosing among biblical sources, a dramatist would probably want to decide whether or not to depict Mary Magdalene as the first individual to see the risen Christ, as in John's Gospel, whether or not Christ first greets her disguised as a gardener, and whether or not he appears to the three Marys together or to Mary Magdalene alone and then separately to the other two. Later traditions produce other difficult choices for dramatists. For instance, major consequences to the composition would ensue if the dramatist were to decide to include the three Marys' dialogue with an unguent merchant, which often runs to enormous length and (sometimes comic) complexity in fourteenth- and fifteenth-century Latinvernacular Easter dramas from the German lands and Bohemia. Several contradictory traditions may even appear in the same work. The manuscripts of the Chester cycle, for instance, vary with regard to the inclusion of Mary Magdalene's encounter with Jesus as the gardener (18, lines 421-33; see appendix Id in the Lumiansky and Mills edition). In Towneley 26 she is the crucial bearer of the Resurrection message-even when the previous play of this cycle has implied that the other two Marys would likely reach the apostles with the news first.

Because of its fragmentary state, perhaps, the Shrewsbury Officium Resurrectionis lacks many of the chants that conventionally appear in medieval Easter ceremonies, or Osterfeiern, and in later dramas. The history of the Osterfeiern began in roughly the ninth century with the "Quem quaeritis" dialogue. According to Timothy McGee, it was usually performed as an introductory trope or in a procession before the Introit antiphon for the Easter Mass or in the office of matins

\footnotetext{
${ }^{12}$ Luke does not name the women (24.1-9); Matthew lists Mary Magdalene and "the other Mary" (28.1-7); and John identifies only Mary Magdalene (20.1-18).
} 
on Easter morning between the last responsory and the Te Deum. ${ }^{13}$ Over roughly the next three hundred years, this central dialogue between the three Marys and the angel was extended through several new chants, including a dramatic performance of the Easter sequence "Victimae paschali laudes" and the Te Deum. The results were what Carl Lange calls the Type II and Type III Osterfeiern. ${ }^{14}$ Further examinations of the dramatic texts by de Boor and of their musical settings by Rankin and Norton have shown that the medieval repertory of Osterfeiern reflects broad regional organization, with a small number of groups, which, generally speaking, distinguish French melodies from German ones and occasionally ones from Prague. ${ }^{15}$ It is difficult to determine, on the basis of music, the regional group to which the Shrewsbury Officium Resurrectionis might belong because the text appears to record only an upper-voice part - not the tenor, which would probably reproduce the melody of the chant.

\section{Analogues for the Shrewsbury OfFicium ResurReCtionis: Plays from Ireland and France}

Davis's search among insular texts for dramas similar to the Shrewsbury Fragments led him to a Visitatio sepulchri in a processional book from the Church of St. John the Evangelist in Dublin (Oxford, Bodleian Library, MS Rawlinson Liturg. d.iv). The Dublin Visitatio, a text entirely in Latin, exhibits a structure similar to that of its Shrewsbury counterpart. ${ }^{16}$ The Dublin play includes the same passages except for the lyric "Heu! cur ligno" (Officium Resurrectionis, lines 8-11), which

${ }^{13}$ Timothy McGee, "The Liturgical Placements of the Quem quaeritis Dialogue," Journal of the American Musicological Society 29 (1976), 2 and 14. Nils Holger Petersen surveys the history of criticism concerning the medieval Easter drama in "Liturgical Drama: New Approaches," in Bilan et perspectives des études médiévales (1993-1998), ed. Jacqueline Hamesse, Textes et Études du Moyen Age 22 (Turnhout, 2004), pp. 625-44. For the relationship between the Quem quaeritis trope and the Easter drama, see C. Clifford Flanigan, "The Liturgical Context of the Quem queritis Trope," Comparative Drama 8 (1974), 45-62.

${ }^{14}$ Carl Lange, Die lateinischen Osterfeiern: Untersuchungen über den Ursprung und die Entwickelung der liturgisch-dramatischen Auferstebungsfeier mit Zugrundelegung eines umfangreichen, neuaufgefundenen Quellenmaterials (Munich, 1887). We use Lange's typology only as a point of reference. The fact that medieval authors exhibit great freedom in composing Easter plays from diverse liturgical and nonliturgical material shows that these plays defy absolute classification. No study of the medieval Easter drama can completely avoid what Hansjürgen Linke has called the "chaotischen terminologischen Gebrauch" that has become a legacy of this scholarship. See Linke, "Osterfeier und Osterspiel," in Osterspiele: Texte und Musik. Akten des 2. Symposiums der Sterzinger Osterspiele (12.-16. April 1992), ed. Max Siller, Schlern-Schriften 293 (Innsbruck, 1994), p. 123, and his survey of the problem of terminology and classification on pp. 121-23. See also Karl Young's commentary in The Drama of the Medieval Church, 2 vols. (Oxford, 1933), 1:239-410. The most complete edition of the repertory of Osterfeiern is by Walther Lipphardt, Lateinische Osterfeiern und Osterspiele, 9 vols., Ausgaben deutscher Literatur des XV. bis XVIII. Jahrhunderts, Reihe Drama, 5 (Berlin, 197590).

15 Rankin, "The Mary Magdalene Scene"; Norton “On 'Stages' and 'Types."

16 Walther Lipphardt has argued on the basis of musical evidence in one of the Dublin chants, "Iam iam ecce," that the source for this Dublin play is related to dramas from Tours and Fleury. See Die Weisen der lateinischen Osterspiele des 12. und 13. Jabrhunderts, Musikwissenschaftliche Arbeiten 2 (Kassel, 1948), pp. 22-23. 
appears in no other source of which we are aware. The Dublin text also includes passages that are missing from the Shrewsbury drama: the complete parts for Prima and Secunda Maria, the "Quem quaeritis" dialogue with the angel, and a Latin version of the "Alleluya" that appears in an English paraphrase at lines 3033 of the Shrewsbury play. But Davis himself admits that some of the texts in the Visitatio occur in many other sources. ${ }^{17}$

Since 1933, scholars of English religious drama have tended to support the view of Karl Young that the twelfth- and thirteenth-century sources of the Easter plays from France are the most important surviving cognates for the Shrewsbury Resurrection fragment. ${ }^{18}$ These Visitatio plays, from Rouen, Tours, Fleury, and Origny, preserve all of the Latin texts that appear in the corresponding play from Shrewsbury except "Heu! cur ligno." ${ }^{19}$ However, the elaborations of Scripture that occur in the plays from Tours, Fleury, and Origny far exceed those in the Shrewsbury Officium Resurrectionis, at least insofar as one can tell from the fragments that remain. Of the French works, the play from Origny-St.-Benoit seems to be the one most closely related to the Shrewsbury Resurrection fragment because the Origny drama includes vernacular texts that translate and paraphrase the Latin ones that precede them. Tours and Origny also include passages from what Wilhelm Meyer calls the Zehnsilberspiel, a Latin drama that consists mainly of stanzas in rhymed decasyllabic verse. ${ }^{20}$ These lyrics form a secondary, nonscriptural drama that mostly precedes the action one finds in the English play; this secondary work is integral to many of the Continental dramas to which it is connected. In theory, the Zebnsilberspiel includes the lament that the three Marys sing on their way to the tomb, their dialogue with the merchant from whom they purchase unguent in order to anoint the body of Christ, ${ }^{21}$ Mary Magdalene's lamentation at the sight of the empty tomb, her dialogue with the risen Christ, and her conversation with the apostles. ${ }^{22}$ Walther Lipphardt's musical analysis of several stanzas from the Zehnsilberspiel- "Sed eamus et ad eius properemus tumulum," "Heu nobis internas mentes," and "Cum venissem ungere mortuum"- - from sources in the German lands, Bohemia, France, and Italy shows that certain melodic settings of the

${ }_{17}$ Davis, ed., Non-Cycle Plays and Fragments, p. xvii.

${ }_{18}$ Young, The Drama of the Medieval Church, 2:514-23.

${ }^{19}$ See E. de Coussemaker, Drames liturgiques du moyen âge (Rennes, 1860; repr., New York, 1964), pp. $250-53,21-36,178-87$, and 256-70.

${ }^{20}$ See Wilhelm Meyer, "Fragmenta Burana," Festschrift zur Feier des hundertfünfzigiäbrigen Bestehens der Königlichen Gesellschaft der Wissenschaften zu Göttingen: Abhandlungen der philologischhistorischen Klasse, [part 1] (Berlin, 1901), pp. 91-118.

${ }^{21}$ Meyer posits that the $\mathrm{B}$ and $\mathrm{C}$ stanzas of the Zehnsilberspiel were composed in France and were later integrated into the corpus of German dramas. See "Fragmenta Burana," p. 118.

${ }^{22}$ The Zehnsilberspiel is hypothetical because there is no known complete exemplar. The full theoretical form of the drama, according to Meyer, consists of six groups of stanzas (A-F), some with quindecasyllabic and octosyllabic lines. See "Fragmenta Burana," pp. 91-118; and Young, Drama of the Medieval Church, 1:677-82. De Boor, in contrast, writes that the "Zebnsilberspiel ist eine Fiktion" and that it should be considered merely a new verse form of the Osterfeier (Lateinische Osterfeiern, pp. 239-40). 
texts were rather widespread and indicate a conscious program of strophic variation. ${ }^{23}$

\section{ANAlogues for the SHREWSbury OfFicium ResurReCtionis: German Plays}

E. K. Chambers appears to have been the first scholar of English drama to identify connections between the repertory of medieval German Easter plays and the Shrewsbury Fragments. He comments briefly about the parallel passages in the Visitatio from Trier (Trierer Osterspiel) and the Shrewsbury Officium Resurrectionis in his study The Mediaeval Stage. ${ }^{24}$ Chambers sees these two plays as examples of transitional works in the evolution of religious drama from sung Latin liturgical plays to spoken ones in the vernacular. This development is clear in these dramas, he says, because the scribe of the play from Trier used the terms "cantat" and "dicit" in rubrics to distinguish between its musical and spoken parts, also because only Latin texts are set to music in the compositions from Shrewsbury. We shall later refute this interpretation of these sources. We also disagree, like O. B. Hardison and de Boor, with the very notion of evolution in religious drama from simpler to more complex forms. ${ }^{25}$

In English Religious Drama of the Middle Ages, Craig seems to agree with Chambers and Young when he says that English plays "present among themselves the same aspect of variety, both in contents and arrangement, that has appeared ... on the European continent." ${ }^{26}$ But he leaves little hope for making further connections between the Shrewsbury Resurrection fragment and the repertory of German plays because his commentary focuses almost entirely on the vernacular, comedic elaborations about an unguent merchant that were added to the Latin Osterfeier in some of the late-medieval Easter plays from the German lands. Shrewsbury preserves no such elaborations. Rather, the key to the development of medieval English drama, Craig feels, lies in the corpus of religious drama in France; but the French repertory, he laments, is badly preserved. ${ }^{27}$

\section{The Shrewsbury Officium Resurrectionis and Its Latin Cognates: Musical CONNECTIONS}

A careful comparison of the music and texts in the Easter dramas from Trier, Füssen, and Prague (none of which employs the comedic elements that Craig notes) with the one from Shrewsbury reveals correspondences, heretofore unexplored, that are important not only for establishing connections between medieval dramas

2. Lipphardt, Die Weisen der lateinischen Osterspiele, pp. 6-7, 12-13, and 36. The sources include the Trierer Osterspiel and the Ordo trium personarum from Prague.

${ }^{24}$ E. K. Chambers, The Mediaeval Stage, 2 vols. (Oxford, 1903), 2:90.

${ }^{25}$ Ibid., 2:90; O. B. Hardison, Jr., Christian Rite and Christian Drama in the Middle Ages: Essays in the Origin and Early History of Modern Drama (Baltimore, 1965), pp. 178-227; de Boor, Lateinische Osterfeiern, pp. 4-21.

${ }^{26}$ Hardin Craig, English Religious Drama of the Middle Ages (Oxford, 1955), pp. 97-98 and 113.

${ }^{27}$ Ibid., pp. 108-9. 
but also for the suggestions that these connections make about Mary Magdalene's role in the English drama. Except for "Heu! cur ligno," the German and Czech repertory preserves all of the Latin chants in the Shrewsbury text in large numbers, whereas musical notation accompanies only two Latin verses in the English Officium Resurrectionis: "Iam iam, ecce, iam properemus" and "O Deus, quis reuoluet." According to Ernst Schuler's catalogue, Die Musik der Osterfeiern, Osterspiele und Passionen des Mittelalters, a chant setting of "Heu! Redemptio Israel" is preserved in at least eighteen Continental dramas. ${ }^{28}$ All but the sources from Tours and Fleury are of German or Bohemian origin. Nine of these instances of "Heu! Redemptio Israel" appear with musical notation, and five of the others indicate in stage directions that the text is to be sung..$^{29}$ "Iam iam, ecce" is preserved with music as a chant in at least three Continental sources: Tours, Fleury, and the Benediktbeurer Osterspiel. 30 "O Deus, quis revolvet nobis lapidem" occurs as a chant in at least fifty-nine Continental dramas. ${ }^{31}$ Seven of these are in French and Italian sources; six of them are in Edmond de Coussemaker's famous edition, Drames liturgiques du moyen âge. ${ }^{32}$ The other examples of "O Deus, quis revolvet" occur in German and Bohemian dramas. Forty-three of them appear with musical notation; the rest, except for the antiphonaries from Würzburg, Freising, and Harlem, include stage directions that tell the actors to sing the text. ${ }^{33}$

${ }^{28}$ Ernst August Schuler, Die Musik der Osterfeiern, Osterspiele und Passionen des Mittelalters (Kassel, 1951), pp. 208-9. This number of plays includes the Füssener Osterspiel, which is not in the catalogue.

${ }^{29}$ Coussemaker, Drames liturgiques, pp. 24 and 187. Schuler identifies the following German and Bohemian dramas in item 251 of Die Musik der Osterfeiern: Böhmen I. Osterspiel (15th c.); Bozener Passion (15th c.; directions indicate "Maria canit"); Braunschweiger Osterfeier (14th c.); Brixener Passion (1551); Erlau 1II. Osterspiel (15th c.); Frankfurter Dirigierrolle (14th c.; directions indicate "Nach dem Gesang"); Innsbrucker Osterspiel (1391; directions indicate "Maria cantat"); Klosterneuburger Osterspiel (13th c.; no music); Notteln (c. 1420); Pfarrkircher Passion (1486; directions indicate "Maria canit"); Prag, Osterspiel I. (15th c.; no music); Prag, Osterspiel II. (1384); Rheinhessisches Osterspiel (1460; directions indicate "Maria respondet cantando"); Trier Osterspiel (c. 1400); and Wolfenbüttel Osterspiel (14th c.). Unless noted to the contrary, these texts include music. Schuler's number does not include the Füssener Osterspiel (1st half 15 th c.) because its discovery postdated the publication of his catalogue.

${ }^{30}$ Coussemaker, Drames liturgiques, pp. 25 and 187; item 272 in Schuler, Die Musik der Osterfeiern.

${ }^{31}$ See Schuler, Die Musik der Osterfeiern, items 297-301. Our number includes the Füssener Osterspiel, which is not in the catalogue.

${ }^{32}$ Coussemaker, Drames liturgiques, pp. 26, 180, 250, 262, 298, and 307. For an edition of the seventh source from France (St. Ouen Antiphonary, Rouen, Bibliothèque municipale), see Carl Lange, Die lateinischen Osterfeiern, p. 37.

${ }^{33}$ Schuler identifies these German and Bohemian plays in item 525 of Die Musik der Osterfeiern: Augsburger Agende (1547); Bamberger Agende (1587); Benediktbeurer Osterspiel (c. 1300); Böhmen I. Osterspiel (15th c.); Bozener Passion (15th c.; directions indicate "Marie ... canunt"); Braunschweiger Osterfeier (14th c.); Brixener Passion (1551); Deutsches Antiphonar I. (12th c.); Deutsches Antiphonar II. (13th c.); Eger Fronleichnamspiel (15th c.); Einsiedeln I. (12th c.); Einsiedeln II. (13th c.); Engelberg I. (12th c.); Engelberg II. (1372); Erlangen, Osterfeier (16th c.; directions indicate "Mulieres cantant"); Erlau III. Osterspiel (15th c.); Frankfurter Dirigierrolle (14th c.; directions indicate "Maria [recte Mariel . . cantabunt"); Freising (14th c.; no music); Harlem (13th c.; no music); Innsbrucker Osterspiel (1391; directions indicate "persone cantant"); Klosterneuburger Osterspiel (13th c.); Köln Breviar (13th c.); Notteln (c. 1420); Passau I. (14th c.); Passau II. (date uncertain); Passan III. (1514); Passau IV. (1490); Passau V. (1498); Pfarrkircher Passion (1486); Prag I. (14th 
"Surrexit Christus spes nostra" derives from the Easter sequence "Victimae paschali laudes." ${ }^{34}$ Dramatic performances of the sequence occur in twenty-two Continental sources: Tours and twenty-one German and Czech Easter plays. ${ }^{35}$ Four of these Continental dramas appear with musical notation; of the remaining seventeen, only the Böhmer Osterspiel (Böhmen II.) has no stage directions that clearly indicate that "Surrexit Christus spes nostra" is to be sung. ${ }^{36}$ Since the medieval German and Bohemian Easter dramas so closely parallel the form and content of the Shrewsbury Resurrection, their music and stage directions suggest a more musical performance of the English drama. With such evidence in mind, we may then discover what role music might have had in the preaching activities of Mary Magdalene and her companions at the tomb.

\section{The Role of Mary Magdalene in Medieval English Drama}

Mary Magdalene's role as exegete and preacher has long and frequently been acknowledged in the legends about her and in the works of scholars, although the vast majority of these critics have examined English plays almost exclusively when considering her various roles. ${ }^{37}$ For instance, critics have noted that the dramatic situation of the three Marys who arrive at Christ's tomb on Easter morning has

c.); Prag III. (14th c.); Prag IV. (14th c.); Prag V. (14th c.); Prag VI. (14th c.); Prag VII. (14th c.); Prag VIII. (14th c.); Prag, Osterspiel I. (15th c.); Prag, Osterspiel II. (1384); Rheinau I. (12th-13th c.; directions indicate "procedunt ad sepulchrum domini cantantes"); Rheinau IV. (13th c.); Rheinhessisches Osterspiel (1460; directions indicate "cantent simul"); Salzburger Agende I. (1511); Salzburger Agende II. (1575); St. Florian (14th c.); Trier Osterspiel (c. 1400); Weingarten (13th c.); Wien I. (12th-13th c.); Wien H. (1519); Wolfenbïttel Osterspiel (14th c.); Würzburg I. (12th c.); and Würzburg II. (13th c.; no music). Unless noted to the contrary, these texts include music.

${ }^{34}$ Young, The Drama of the Medieval Church, 2:518 n. 1; Schuler, Die Musik der Osterfeiern, item 652.

35 Coussemaker, Drames liturgiques, pp. 35-36.

${ }^{36}$ Schuler identifies these German and Bohemian plays in item 651 of Die Musik der Osterfeiern: Böhmen 1. Osterspiel (15th c.); Böhmen 11. Osterspiel (15th c.); Bozener Passion (15th c.; directions indicate "Maria Magdalena . . . canit"); Braunschweiger Osterfeier (14th c.; directions indicate "cantat jocunda voce"); Brixener Passion (1551); Eger Fronleichnamspiel (15th c.; directions indicate "Maria canit"); Einsiedeln II. (13th c.); Engelberg II. (1372; directions indicate "Chorus"); Erlau III. Osterspiel (15th c.; directions indicate "Maria cantat"); Frankfurter Dirigierrolle (14th c.; directions indicate "cantabunt"); Innsbrucker Osterspiel (1391; directions indicate "Maria cantat"); Pfarrkircher Passion (1486; directions indicate "Magdalena canit"); Prag, Osterspiel I. (c. 1400; directions indicate "Maria cantet"); Prag, Osterspiel II. (1384; directions indicate "cantet"); Rheinau IV. (13th c.; directions indicate "Maria ... redit a sepulchro ... cantando); St. Gallen VI. (1583; directions indicate "incipit chorus"); St. Gallen VII. (1582; directions indicate "chorus incipiat"); Trier Osterspiel (c. 1400; directions indicate "incipiet cantor"); Wiener Osterspiel (1472; directions indicate "Maria singet"); and Wolfenbiuttel Osterspiel (14th c.). Unless noted to the contrary, these texts include music.

${ }^{37}$ See Hans-Jürgen Diller, The Middle English Mystery Play: A Study in Dramatic Speech and Form, trans. Frances Wessels (Cambridge, Eng., 1992), p. 19. For the topic of Mary and preaching in particular, see Theresa Coletti, Mary Magdalene and the Drama of Saints: Theater, Gender, and Religion in Late Medieval England (Philadelphia, 2004), pp. 24, 134-48, and 190-91. See also Katherine Ludwig Jansen, The Making of the Magdalen: Preaching and Popular Devotion in the Later Middle Ages (Princeton, N.J., 2001), pp. 57-59. Coletti and Jansen both provide excellent documentation on this subject. Jansen also provides reproductions of many artworks that portray Mary preaching; see The Making of the Magdalen, pp. 62-82. 
them taking on Christ's preaching role: ${ }^{38}$ the women not only convey to the disciples (a male audience) and to the members of the Easter drama's audience the most significant event in the Savior's story, but they also explain to their audiences at least part of its meaning. Feminist critics in particular have stressed the obvious reversal of the traditional sex roles that is inherent in such activities. For example, the Mary Magdalene of the York cycle says, "And all is for oure goode, / And nothyng for his plight. / Spilte pus is his bloode, / For ilke a synfull wight" (39, lines 122-25). ${ }^{39}$ The idea of teaching is also important to the Shrewsbury Officium Resurrectionis. Tertia Maria calls Jesus "pe best techer in world wide" (line 15), and all three women later declare, "Lettes noght pis lesson be forlorn" (line 42), even though the substance of this "lesson" would seem to be missing from the text as it survives. In contrast, in the sections of the Digby Mary Magdalen that correspond to the Officium Resurrectionis, St. Peter talks about teaching (lines 1046-47); the women do not. In the Bodleian Resurrection in MS e Museo 160, the roles of the male apostles, especially Peter, loom large as compared with their roles in the biblical accounts of the Resurrection and in the earlier Easter plays (lines 267-569).40 But the kinds of results that such comparisons would ideally lead to have been limited because of the relative neglect by scholars of the Bohemian and German dramas.

\section{Mary Magdalene: Singer or SPEAKer?}

In English drama we have found only two passages that are similar to the climax of the Shrewsbury Officium Resurrectionis, the point when the three Marys declare, "Alleluya schal be oure song" (line 30). In the first passage, from the Bodleian Resurrection, where there is a smattering of macaronic verse (e.g., lines 63839) that is somewhat similar to the Latin-vernacular interplay of the Shrewsbury texts, "Mawdleyn" enjoins her heart, "Now may thou entone a mery songe" (line 632). The intentions of the Shrewsbury women come over much more strongly. The second example occurs in the York cycle. Mary Magdalene says, "Alle for joie me likes to synge, / Myne herte is gladder panne pe glee" (lines 134-35). In short, only in the Shrewsbury play and in the Bodleian Resurrection (p. 190) do intentions to sing appear in combination with actual song. Only in the Shrewsbury Resurrection fragment and in the Dublin version (entirely in Latin) do the women indicate a desire to sing "alleluya," the quintessential song of ecstatic praise. Such

\footnotetext{
${ }^{38}$ See Brock, Mary Magdalene (above, n. 1), pp. 9-18 and 161-75; and Esther de Boer, Mary Magdalene: Beyond the Myth, trans. John Bowden (Harrisburg, Pa., 1997), pp. 62-63.

${ }^{39}$ For the subject of reversal of sex roles, see Jansen, The Making of the Magdalen, pp. 57-59; and Coletti, Mary Magdalene and the Drama of the Saints, pp. 138-48.

${ }^{40}$ For the Digby Mary Magdalen and Christ's Burial and Christ's Resurrection from e Museo 160, we use Donald C. Baker, John L. Murphy, and Louis B. Hall, Jr., eds., The Late Medieval Religious Plays of Bodleian MSS Digby 133 and E Museo 160, Early English Text Society, O.S., 283 (Oxford, 1982). In the Digby play Mary delivers two sermons, and the work as a whole certainly promotes her generally and her preaching in particular. However, during the Easter scenes, Lawrence M. Clopper finds that "she subordinates herself and her words to Saint Peter"; see Drama, Play, and Game: English Festive Culture in the Medieval and Early Modern Period (Chicago, 2001), p. 242. This play does not include Mary Magdalene's delivery of the Easter news to the apostles.
} 
desire has more significance during the Easter liturgy than it otherwise would because "alleluya" is omitted from the service throughout Lent.

In contrast, nearly all of the English plays, ${ }^{41}$ while they tend to emphasize the point that the essential Easter message first comes from women, insist that the Marys use only speech to convey this message. In N-Town 36, for instance, Mary Magdalene responds to the angel at the tomb with "As we have herde, so schall we saie" (line 265). When these women (or, in some versions, Mary Magdalene herself) proceed to tell the news of the Resurrection to the male apostles, the English plays usually refer to the women's speaking voices very specifically: "opyn voys and speche expres" (N-Town 36, line 118; see also lines 82, 83, and 151; Chester 18, line 362; Towneley 26, lines 423 and 625-35; and Bodleian Resurrection, lines 661 and 670 ). Such references may appear in these texts because, typically, the female roles in liturgical dramas were played by men. The liturgy can then represent a kind of blending of male and female roles, which can be connected to "ideally" sexless voices and to Christ's blended nature (both human and divine, for instance) as well. Also, correspondences between the three Marys and priests would be clear if the actors playing the roles of the women carried thuribles in place of the women's vessels for spices and oils..$^{42}$

Since critics are almost silent concerning the issue of whether the unnotated passages in the Shrewsbury texts should be spoken or sung, the many references in the corresponding dramas to speaking voices might well nudge a reader's opinion toward speech. However, important evidence in Continental analogues suggests the opposite. Also, there is slight but identifiable evidence in English dramas of women who associate their mourning with both preaching and singing. The beginning of Christ's Burial in Bodleian MS e Museo 160 certainly resembles a sermon. An unidentified character says, "A soule that list to singe of loue / Of Crist [this 'treyte'] ... may hym teche lightly with-awe / Off the sorow of Mary sumwhat to knawe" (lines 1-5). The play then parallels the Virgin's sorrow to that of Mary Magdalene at the sepulcher (line 8). There are also many connections between preaching, singing, and women's sorrow in the traditions of the medieval lyric, and particularly in lyrics that portray the sorrows of Christ's mother. ${ }^{43}$ The Shrewsbury Officium Resurrectionis strongly hints at the act of singing when, at the climax of the play's action, the three Marys announce, "Alleluya schal be oure song" (line 30). Here, rhetoric and song join together in a vernacular exegesis of the Easter story that only becomes clear through a study of the liturgical elements of the Shrewsbury Resurrection fragment and, in particular, those aspects of the liturgy that have cognates in the corresponding German and Bohemian plays. Furthermore, this study shows that the English work may have been even more musical than it at first appears.

${ }^{41}$ We include a large number of depictions of Mary Magdalene in our study for purposes of comparison. We do not mean to imply that English medieval drama makes up a kind of homogeneous body.

${ }^{42}$ See Diller, The Middle English Mystery Play, pp. 15 and 126; and Richard Rastall, Music in Early English Religious Drama, 1: The Heaven Singing (Woodbridge, Eng., 1996), pp. 308-27.

${ }^{43}$ See Baker, Murphy, and Hall, eds., The Late Medieval Religious Plays, pp. lxxxviii-xcv and n. 2. 


\section{The German and Bohemian Plays: Mary Magdalene Preaches}

A selection of three representative plays from the German lands and Bohemia will suffice for the comparison (see the Appendix). The manuscript copies of the Trierer Osterspiel, ${ }^{44}$ the Füssener Osterspiel, ${ }^{45}$ and the Ordo trium personarum from Prague ${ }^{46}$ all stem from the same presumed period as the Shrewsbury Fragments (c. 1430). ${ }^{47}$ Unlike the English plays that have attracted so much attention from English-speaking scholars, these Latin-vernacular Easter plays exhibit very close parallels to the content of the corresponding Shrewsbury drama: they include the same Latin texts and surround many of them with both Latin and vernacular lyrics that elaborate on the scriptural narrative of the Visitatio sepulchri. The neglect of these obvious parallels is surprising since the elaborations follow a pattern that is common to many medieval Easter dramas from the region and since this pattern is readily observable in a number of formal studies of the medieval German and Czech Easter dramas that have appeared over roughly the last 160 years. Especially important are the studies of Franz Joseph Mone, Ignác Jan Hanuš, Gustav Milchsack, Richard Froning, Wilhelm Creizenach, Jan Máchal, Eduard Hartl, František Svejkovský, and Ruprecht Wimmer. ${ }^{48}$ More generally, a

${ }^{44}$ The Latin-German play known as the Trierer Osterspiel (Trier) appears on pages 19-30 of a paper manuscript with modern pagination. The manuscript, Trier, Stadtbibliotek, MS 1973/63, which dates from the first half of the fifteenth century, also includes a dramatic lament of the Blessed Virgin Mary (Marienklage). See the facsimile edition by Ursula Hennig and Andreas Traub, Trierer Marienklage und Osterspiel, Codex 1973/63 der Stadtbibliothek Trier, Litterae 91 (Göppingen, 1990); and Rolf Bergmann, Katalog der deutschsprachigen geistlichen Spiele und Marienklagen des Mittelalters (Munich, 1986), pp. 345-47.

${ }^{45}$ The Latin-German play now known as the Füssener Osterspiel (Füssen), formerly known as the Harburger Osterspiel, is on fols. $137 \mathrm{r}-141 \mathrm{r}$ of a paper manuscript that also includes Latin grammatical texts, a calendar of feasts associated with a Cistercian convent in Heilsbronn, and a Marienklage. The manuscript, Augsburg, Universitätsbibliothek, Cod. II.1.4 .62 , was first discovered in the monastic library of St. Mang in Füssen. Codicological evidence suggests that the gathering that includes the Füssener Osterspiel was copied in the first half of the fifteenth century. See the facsimile edition by Dietrich Schmidtke, ed., Das Füssener Osterspiel und die Füssener Marienklage, Universitätsbibliothek Augsburg (ehemals: Harburg), Cod. II, 1, 4․ 62, Litterae 69 (Göppingen, 1983); and Bergmann, Katalog, pp. 52-53.

${ }^{46}$ The Ordo trium personarum (Prague) was edited by Jan Máchal in Staročeské skladby dramatické, původu liturgického, Rozpravy České Akademie Císaře Františka Josefa pro Vědy, Slovesnost a Umění 3/23 (Prague, 1908), pp. 98-105; see also the facsimile, plates 1-5. Máchal also uses the Czech title for this Latin-Czech drama: Pruni hra tř́ Marii (First Play of the Three Marys). The text is on fols. $135 \mathrm{v}-137 \mathrm{v}$ of Prague University Library MS I.B.12, a manuscript copied in 1384 that also includes a cycle of sermons on the saints, fragments of legends, and two Passionale texts.

${ }^{47}$ On the date of the Shrewsbury Fragments see Kurt von Fischer, "Die Passion von ihren Anfangen bis ins 16. Jahrhundert," in Gattungen der Musik in Einzeldarstellungen: Gedenkschrift Leo Schrade, ed. Wulf Arlt et al. (Bern, 1973), p. 592.

${ }^{48}$ Franz Joseph Mone, Schauspiele des Mittelalters (Karlsruhe, 1846); Ignác Jan Hanuš, ed., Die lateinisch-böhmischen Oster-Spiele des 14.-15. Jahrbunderts (Prague, 1863); Gustav Milchsack, Die lateinischen Osterfeiern (Wolfenbüttel, 1880); Richard Froning, Das Drama des Mittelalters: Die lateinischen Osterfeiern und ibre Entwicklung in Deutschland (Stuttgarr, 1891-92; repr. Darmstadt, 1964); Wilhelm Creizenach, Geschichte des neueren Dramas, 1 (Halle, 1893); Máchal, ed., Staročeské skladby dramatické; Eduard Hartl, Das Drama des Mittelaters, Osterspiele, mit Einleitungen und 
glance at the German dramas helps one to understand the corresponding English plays because the German ones give up the history of vernacular elaborations of the Easter story more readily than the English ones, and an understanding of this history should make our suggestions concerning the Shrewsbury Resurrection play seem more probable.

By no later than the first half of the fourteenth century, playwrights working in the German lands and Bohemia began to mingle vernacular lyrics with passages from the "Quem quaeritis" dialogue, Latin chants, and stanzas of the Zehnsilberspiel. The earliest extant examples of this form of bilingual Easter drama in these regions are the Latin-German play known as the Münchener Hortulanusszene (Munich, Bayerische Staatsbibliothek, Cgm 5249/57)49 and the Latin-Czech drama known as Mastičkár Musejní (Prague, National Museum). ${ }^{50}$ In these plays the vernacular songs of the three Marys do not simply translate the Latin lines with which they are paired but paraphrase and elaborate on them. The German lyrics in the Münchener Hortulanusszene all appear with musical notation in campo aperto (staffless neumes notated above the text). The stage direction "Planctus ille etiam est cantandus" suggests that these melodies are variations of the one to which the preceding Latin text, "Dolor crescit tremunt precordia," is set. Of course, one cannot prove an actual connection on the basis of the campo aperto neumation, because it offers no indication of pitch, but there is a very distinct similarity between the neumation of the decasyllabic text "Dolor crescit" and of the following German song "We der maere." ${ }^{1}$ Apparently, in this early model for the German Easter dramas, vernacular lyrics-both their texts and the music that binds them together-elaborated on, varied, and reinterpreted the Latin that surrounds them, just as we propose for the Shrewsbury play.

In the German plays the emotional point of departure for these elaborations and reinterpretations, which causes a new mode of expression to emerge, is the emotional state of Mary Magdalene. All three Marys sing "Heu! Redemptio Israel" in the Füssener Osterspiel, though Mary Magdalene alone sings this antiphon in the plays from Trier and Prague. In the Trierer Osterspiel, Tertia Maria (or Tertia Persona) then apparently sings "Dolor crescit" and all of the remaining Mary lines after line 72, and after line 99 in the play from Prague, including the

\footnotetext{
Anmerkungen auf Grund der Handschriften (Leipzig, 1937; repr. Darmstadt, 1969); František Svejkovský, Z dějin céského dramatu: Latinské a latinskočeské bry trí Marii [From the history of Czech drama: The Latin and Latin-Czech plays of the Three Marys], Acta Universitatis Carolinae, Philologica Monographia 12 (Prague, 1966); Ruprecht Wimmer, Deutsch und Latein im Osterspiel: Untersuchungen zu den volkssprachlichen Entsprechungstexten der lateinischen Strophenlieder, Münchener Texte und Untersuchungen zur deutschen Literatur des Mittelalters 48 (Munich, 1974).

${ }^{49}$ Meyer notes that the so-called Münchener Hortulanusszene (Munich, Bayerische Staatsbibliothek, Cgm 5249/57) represents the earliest-known example of this practice in a German Easter drama. See "Fragmenta Burana," p. 140. He refers to this play as the Münchener Bruchstück des lateinischdeutschen Marienspiels in Zehnsilbern, while Bergmann refers to it as the Münchener Hortulanusszene in his Katalog, pp. 264-66. A facsimile of the Münchener Hortulanusszene appears in an appendix (plates 14 and 15) to the "Fragmenta Burana."

${ }^{50}$ The manuscript of this work dates to the mid-fourteenth century. Scholars agree, however, that an earlier copy, c. 1325-33, existed. See Veltruský, A Sacred Farce, pp. viii and 74.

${ }^{51}$ Meyer, "Fragmenta Burana," plates 14-15.
} 
dialogue with the risen Christ and then with the apostles. The emotional tension increases as, in "Heu! Redemptio Israel," Mary Magdalene (or all the Marys in the Füssener Osterspiel) laments Christ's death. Then the most significant parallel between the Shrewsbury Officium Resurrectionis and the German and Czech plays occurs. The vernacular texts that follow the Latin chant in each of the German and Czech plays are exegetical. In the play from Trier, Mary Magdalene teaches by example, borrowing themes from the "Dolor crescit" chant to reflect on the agony of Jesus and on the seven "dufellen," demons of sin from which he rescued her. ${ }^{52}$ She thus reflects on the same moral themes found in the Shrewsbury Fragments (see the Appendix). That is, the Marys, or Mary Magdalene individually, explain to their audiences the crucial message of the Crucifixion: that Christ redeemed people from sin-or "sekenes" (Officium Resurrectionis, line 7)-through his suffering: "Oure hope, oure help, oure hele, is he" (line 39).

\section{The German and Bohemian Plays: Mary Magdalene Sings}

The moment of Tertia Maria's exegesis of the Latin text "Heu! Redemptio Israel" is also significant to our argument because evidence in the German and Czech dramas shows that it was usually performed with music. It seems possible, then, that "Heu! Redemptio Israel" in the Shrewsbury play may also have been sung, perhaps to a melody similar to the variant readings preserved in the analogues. All three of the plays from Trier, Füssen, and Prague contain variant readings of the text and music for this chant (see the Appendix, 1.a, 1.c, and 1.e). The mode-one settings (final on D) that appear in Trier and Prague are similar enough to suggest that they are redactions of the same melody, ${ }^{53}$ and the tune in the Füssener Osterspiel accords with the Trier and Prague analogues in the second half of its line. However, these analogues are not in complete concordance. The direction "cantat rigmatice" that precedes "Heu! Redemptio Israel" in the drama from Trier does not occur with this chant in the other dramas under consideration here. The direction seems to suggest that the performer should sing in a rhythmic style, that is to say, using an accentual manner of declamation for this monody. Also, the fact that the Ordo trium personarum reserves its final cadence for the third line suggests that it transmits a more complete version of the chant than do the German plays. Lipphardt's broad analysis of musical settings for "Heu redempcio nostra" (similar to "Heu! Redemptio Israel") in plays from the German lands, France, and Dublin shows, moreover, that the melody for this chant was quite widely distributed. ${ }^{54}$ This musical evidence further supports our idea that the Shrewsbury Resurrection fragment is connected to the plays from the German lands and Bohemia.

The Shrewsbury Officium Resurrectionis does not indicate how the vernacular text "Allas! he pat men wend" (line 4) should be performed. It may have been

${ }^{52}$ In Luke 8.2 Jesus liberates Mary of Magdala from seven devils.

${ }^{53}$ This music also survives in the sources from Tours and Fleury.

${ }^{54}$ Lipphardt, Die Weisen der lateinischen Osterspiele, pp. 17 and 21. 
spoken; but it seems possible that the performer was meant to adopt a musical practice, as one finds in the parallel lyrics in the Trierer Osterspiel, Füssener Osterspiel, and Ordo trium personarum. The melodies to which "Myn leyd dat wysset" and "O we, o we, got Jh[esu]s erzage dich" are set are also in mode one. In fact, they are variations of the "Heu! Redemptio Israel" melody (Appendix, 1.b and 1.d). The matter is clarified in the play from Prague. Although it does not transmit a melody for the parallel Czech lyric "Awech, mnye hubenyczy" (Alas, wretched me), the direction that precedes it, "eadem nota cantet in vulgari," indicates that the vernacular text was to be sung to the same melody as "Heu! Redemptio Israel" (Appendix, 1.f).55 This musical interpretation of the Latin chant in vernacular verses thus seems to reinforce one's sense of the parallels between the content of these plays.

By making a few more connections between the Shrewsbury Resurrection fragment and Continental dramas, one may construe possibilities for a musical performance of the English text. The musical settings for the messages of grief and redemption in "Myn leyd dat wysset" and hope for Jesus's return in " $\mathrm{O}$ we, o we, got Jh(esu)s erzage dich" are slightly more melismatic than the Latin chant that precedes them. The melismas on words such as "trurych" (wretched), "ghestorben" (dies), and the exclamation "O we" (alas) underscore Mary's agony. A formal analysis of the melody in $1 . \mathrm{b}$ in the Appendix reveals an AAB form, typical of Minnesang and also the Töne sung by late-medieval Meistersinger. The first two lines of the lyric-the two Stollen of the Aufgesang-bear the same initial and cadential formulae. The Abgesang, beginning with the words "Der mych van sewen dufellen," explores the upper range of the mode before descending to the final. The setting of "O we, o we, got Jh(esu)s erzage dich" in the drama from Füssen follows more closely the contour of its model. The only important distinction in this variation comes at the final cadence (on D), which involves a descent from B-flat instead of A (perhaps an error) and simple repetition of the final D instead of pitch inflection. Considering now the parallel circumstance in the Shrewsbury drama, "Allas! he pat men wend" might have been sung to the same melody as "Heu! Redemptio Israel" or to a varied form of it.

In corresponding fashion, the vernacular text "Allas, pat we suche bale schuld bide" (line 13), which follows the Latin "Heu! cur ligno" in the Shrewsbury Officium Resurrectionis (even though "Heu! cur ligno" does not occur in any of the German or Czech dramas), follows a very similar pattern of exegesis to the one found in several of the German and Czech songs that occur at this point in each of the other dramas: "Owe owe der vyll grymmygen hant" (Trier, line 10); "Jesus, din geit dich bezwungen haut" (Füssen, line 23); "Poydem skuoro k gyeho hrobu" (Prague, line 60); and "O we, o we, o we, wir a(r)men frawen" (Füssen, lines 100101). In these songs, Mary (or the three Marys) pauses in her narrative of the Resurrection, just as Tertia Maria does in "Allas" from the Shrewsbury play, in order to reconsider and reflect on the gruesome details of the crucifixion and the pain that Jesus bore. They also preach about the message of redemption inherent

${ }^{s s}$ We wish to thank Dr. Hana Vlhova for her assistance with the Czech text in the Ordo trium personarum. 
in these events by means of both words and music: the German lyric "O we, o we, o we, wir a(r)men frawen" is through-composed to a mode-one melody (Appendix, 2). This music is appropriate to declamation because it evokes the qualities of a psalm tone through its narrow range and frequent statement and decoration of the reciting pitch on A. Thus, the setting for this German vernacular text suggests further possibilities for a musical performance of "Allas" in the Shrewsbury Resurrection fragment - it may have imitated the sound of a psalm tone.

The vernacular texts that follow this passage in each of these plays offer similar exegeses of the previous Latin. The Shrewsbury text gives no details about the way "He pat pus kyndely vs" (line 26) was to be performed. Directions in the play from Füssen confirm that Prima Maria sang "Wer hebt vz den stein" (line 39), but the melody is not extant. The direction "ricmum subiungant" for "Ktho nam ten kamen otlozy" (line 67) in the play from Prague indicates that the singers were to "subjoin" the Czech rhythmus to the previous Latin chant; however, since its setting does not survive, it is difficult to say what the method of performance would have been. In other plays belonging to the German repertory, the verb subiungere sometimes refers to a vernacular text that is notated with music. ${ }^{56}$ But if either of the vernacular texts here were meant to have been sung to the same melody as "O Deus, quis reuoluet," it would have to have been modified considerably in order to accommodate these texts, which are of varying lengths. Nevertheless, it seems possible that "He pat pus kyndely vs" could have been sung to some varied form of the melody for "O Deus, quis reuoluet," in light of the information we have about the performance of "Heu! Redemptio Israel" and its vernacular counterparts (Appendix, 1.a-f).

\section{Terms for Speaking and Singing in the German and Bohemian Plays}

In the Trierer Osterspiel, Mary Magdalene is directed to speak ("dicit") her German rickmus, "Wer wyl vns van dyßem grabe" (line 37). This direction does not occur in the Shrewsbury Officium Resurrectionis or its other analogues; nevertheless, it offers important information about musical practices in these plays on the Continent. The verb dicere often appears in directions for lines in German and Czech dramas, but, significantly, the term seems not to refer to conventional speech. To be sure, the direction "dicit rickmum" (or variations of it) frequently precedes vernacular texts in the plays from Trier, Füssen, and Prague that lack musical settings, but the same direction also refers to Latin chants. The direction for the chant "Quem queritis" (Trier, line 41), for example, is "dicit rickmum." In the repertory of medieval German dramas, the verb dicere appears in the directions for many other Latin chants that come with music. ${ }^{57}$ This irregular usage has led scholars to differing conclusions. Karl Dreimüller, Hansjürgen Linke, and

${ }^{56}$ See, for example, the setting of "Tibi, Symon, habeo" (lines 461-64) of the Wiener Passionsspielfragment, copied c. 1300: Ursula Hennig, ed., Das Wiener Passionsspiel: Cod. 12887 (Suppl. 561) der Österreichischen Nationalbibliothek zu Wien, Litterae 92 (Göppingen, 1986).

${ }^{57}$ See the citations for Latin lines in Schuler's Die Musik der Osterfeiern. 
Ulrich Mehler generally agree that the direction "dicit rickmum" may have approached the musical quality of recitative of the sort that a typical churchgoer would have heard in the reading of the lessons, Epistle, or Gospel. ${ }^{88}$ Wolfgang Suppan proposes that "dicit rickmum" might have sounded like church psalmody. ${ }^{s y}$

The "dicit" direction affects one's assessment of the musical character of the Shewsbury liturgical dramas and of other dramas in this sphere that include alternating Latin and vernacular lyrics. Richard Heinzel suggests that, when Middle High German songs under the "dicit" direction alternate with musically notated Latin texts that have the same form as the German, the term "dicit" does not necessarily mean that the German texts are to be spoken..$^{60}$ Linke has proposed that, since the term "dicit" often describes the performance of plainchant in the German dramas, one could argue that a musical practice would also be appropriate for German texts that have the same stage direction. ${ }^{61}$ The same condition would likely persist for the vernacular texts that do not already have a clear musical direction in the play from Prague, at least when the lines in Czech have the same meter and length as the Latin lines with which they are paired. ${ }^{62}$ This point of view contradicts Chambers and others who have recognized works like the Trierer Osterspiel and the Shrewsbury Resurrection play as transitional works from sung Latin to spoken vernacular drama. ${ }^{63}$ Indeed, performances of the German and Czech works may have been even more thoroughly musical than their examples of notated music suggest, and so may be their close relative from Shrewsbury, for which much less information about musical practice remains extant. These possibilities suggest that the singers in the Shrewsbury play may have sung the vernacular text melodically or in the style of recitative.

\section{Lyrical Parallels between the English Play and the Continental Dramas}

The closing passages of the Trierer Osterspiel, Füssener Osterspiel, and Ordo trium personarum include a dramatic reading of the sequence "Victimae paschali laudes." The Trier play indicates this fact only in the directions after line 179, while the Füssen and Prague works transmit the lines of the sequence. This makes it easier to see that the text "Surrexit Christus, spes nostra" in the Shrewsbury Officium Resurrectionis coincides with the lyrical program of the two Continental

\footnotetext{
${ }^{58}$ See Ulrich Mehler's Dicere und cantare: Zur musikalischen Terminologie und Aufführungspraxis des mittelalterlichen geistlichen Dramas in Deutschland, Kölner Beiträge zur Musikforschung 120 (Regensburg, 1981).

${ }_{54}$ Wolfgang Suppan, “Zur Musik der 'Erlauer Spiele,'” Studia musicologica Academiae scientiarum Hungaricae 11 (1969), 420.

${ }^{60}$ See Richard Heinzel, Beschreibung des geistlichen Schauspiels im deutschen Mittelalter (Hamburg, $1898)$, p. 78.

${ }^{61}$ See Hansjürgen Linke's review of Die deutschen Oster- und Passionsspiele des Mittelalters, by Rolf Steinbach, in Anzeiger fïr deutsches Altertum und deutsche Literatur 83 (1972), 202.

${ }_{62}$ Veltruský, however, argues that several of the verse forms in the play have the same character as Old Czech spoken verse; hence, these lines were probably spoken. See A Sacred Farce, p. 75.

${ }_{6.3}$ See Chambers, The Mediaeval Stage, 2:28.
} 
plays. Although the three dramas from the Continent do not preserve music for these lines, the directions that precede the sequence indicate that the lines were to be sung (see the Appendix).

The emotional climax of this series of vernacular lyrics in Shrewsbury occurs with Mary Magdalene's lyric "Crist is rysen" (line 37). Like that passage, "[N]u myrcket alle crystenlude" (Trier, line 156) and "Crist mein trost ist er standen" (Füssen, line 169) are juxtaposed with "Victimae paschali laudes" and elaborate on the spiritual themes expressed in the sequence. General parallels between the lyrics are obvious, as Mary announces the Resurrection of Christ and expresses her desire to disseminate that knowledge in Galilee. Furthermore, these vernacular texts in the plays from Shrewsbury and Trier develop the theme of preaching, which is implied in the sequence itself. As for more specific parallels that might provide clues to the content of the passages missing from the Shrewsbury Officium Resurrectionis, one might note that, though the "lesson" of the story of the Resurrection that Tertia Maria mentions is not clear in the English drama, it is clear in the parallel text from Trier. Here Mary Magdalene pointedly addresses the Christians standing before her: "myrcket alle crystenlude" ("take note, all Christian people"; line 156). Appropriately, the news that she offers is accompanied by phrases that draw attention to the medium of language: "I must tell you that truly" and "I inform you completely." ${ }^{4}$ These phrases not only stress the significance of her news but also suggest that the very mode of communication that she is using is under stress and that she must make a heroic effort to make herself both understood and believed. She then preaches extreme emotions that would seem to be almost overwhelming: that the assembly should be overjoyed at her news and set aside all mourning (lines 179-80). But she also admonishes them lest they "forget" the message in the Passion: Jesus paid dearly for their redemption from sin and eternal torment with his agony and rosy red blood (lines 173-76).

\section{Mary Magdalene Preaches and Sings}

So, once again, the similar programs of literal exegesis in these dramas open the way to musical interpretation. Might one construe a musical performance of "Crist is rysen" on the basis of the practice conveyed in the Continental exempla? Neither of the German texts is set to music, but the direction "dicit rickmum" for the vernacular text in the Trierer Osterspiel suggests, nevertheless, that the performer might have performed it musically-perhaps after the fashion of liturgical recitative or to a modified form of the melody used in the Latin sequence.

In sum, our first substantive conclusion concerning the Shrewsbury Officium Resurrectionis is that a comparison between this work and German and Czech analogues indicates the possible delivery in song by the three Marys of vernacular exegesis of Latin texts at the climax of the English play. Our second substantive conclusion relies on the first: Mary Magdalene's role in the Shrewsbury plays and in medieval drama more generally is strongly intensified by her ability to communicate through music, as we have already suggested by referring to the mount-

64 "Ich verkundygen uch genczlichen. ... Ich mueß daz werlich jeheen" (Trier, lines 159 and 162). 
ing emotional tension of the English, German, and Bohemian Easter dramas. Certain social and cultural movements of the Middle Ages form a background to the intensification of Mary Magdalene's role. The most important of these is the singular and remarkable significance to theologians, dramatists, and their audiences in the Middle Ages (and, hence, to performers and their audiences as well) of Mary herself. Even as early as the late twelfth century, hagiographers emphasized her potential as a role model for women, her capacity to preach, and the delivery of the Easter message as her primary and formative instance of preaching. By the later Middle Ages, she had become an even more important mystic, visionary, and charismatic figure: "a powerful exemplar" for the devotion of laypeople in general and for "medieval holy women in particular." ${ }^{5}$ At the very least, then, if the Shrewsbury Fragments turn out to be early examples of their genre, then it would appear that the growing popularity of Mary Magdalene started earlier in England than has been thought.

Another cultural movement that helps to form the background of Mary's role is the increasing use of the vernacular in literary compositions throughout the Middle Ages. Within the continual debate during the medieval period about the role of learning in the life of the individual, women's abilities to read and interpret Scripture and other works were matters of heated controversy, ${ }^{66}$ while women were often associated with reading, writing, interpreting, and preaching in the vernacular languages as opposed to the more clerical (and therefore more maleoriented) Latin language. ${ }^{67}$ The Shrewsbury Fragments could well participate in this debate and controversy. There are many more English lines in these plays than Latin ones, and the content that is preserved suggests that any viewer who knew only English and not Latin could follow the action of these dramas without difficulty. Such content, with a unique pattern of switching from Latin to English and back again, could be read as a kind of political statement in favor of vernacular exegesis. Lines such as "Right is pat we reherce by raw / Pe materes bat we may on mene" can even be interpreted as statements in support of a vernacular, lay-preaching cause (Officium peregrinorum, lines 24-25). Also, the vernacular languages are more likely than Latin to be associated with speech as opposed to written tradition, and there are strong connections between women and speech in many of the Easter plays, including the Shrewsbury examples (Officium peregrinorum, lines 15-17; N-Town 36, lines 2, 87-93, and 151).

\footnotetext{
${ }^{65}$ In some works she is even able to appropriate male power, according to critics. See Coletti, Mary Magdalene and the Drama of the Saints, pp. 101 and 129 and also pp. 3 and 133-39; Blamires, The Case for Women, p. 191; Claire M. Waters, Angels and Earthly Creatures: Preaching, Performance, and Gender in the Later Middle Ages (Philadelphia, 2004), pp. 115-18; and Mimi Still Dixon, "Thys Body of Mary': 'Femynyte' and 'Inward Mythe' in the Digby Mary Magdalene," Mediaevalia 18 (1995), 221-44, at pp. 230-31. The Bodleian Resurrection opens with Mary Magdalene offering a lament in the form of a sermon that compares Christ's fate with that of many Old Testament figures. The passage implies that women can preach just as readily and skillfully as men: it is both lengthy and learned (lines 1-42).

${ }^{66}$ See Alcuin Blamires, ed., with Karen Pratt and C. W. Marx, Woman Defamed and Woman Defended: An Anthology of Medieval Texts (Oxford, 1992), pp. 1-15.

${ }^{67}$ See Nicholas Watson's essay, "The Politics of Middle English Writing," in Jocelyn Wogan-Browne et al., eds., The Idea of the Vernacular: An Anthology of Middle English Literary Theory, 1280-1520 (University Park, Pa., 1999), pp. 331-52. See also pp. 73, 114-15, 120-22, and 157-62 of this volume.
} 
The promotion of Mary Magdalene as a cultural figure and the widening use of vernacular languages in literary composition relate to yet another cultural movement of the Middle Ages: the "profeminine" movement. ${ }^{68}$ A discussion of the Shrewsbury Fragments' possible participation in this movement leads in turn to a discussion of whether Mary Magdalene's new mode of expression can be considered a specifically feminine mode of expression.

\section{Mary Magdalene as a Profeminine Figure}

Any composition that portrays women being made responsible for conveying a "lesson," let alone any work that features a preaching moment for three women, would seem to be promoting an active, even activist, role for women in matters of religion. ${ }^{69}$ The German plays would certainly seem to support a profeminine position by presenting Mary Magdalene as such a positive, expressive, and selfconscious figure (Trier, lines 156-80). But the Shrewsbury Officium Resurrectionis's fragmentary state renders any conclusions about how much it advocates these roles speculative. After all, one cannot be sure that the preaching moment takes place in this play. ${ }^{70}$ One can nevertheless rehearse the various traditions concerning advocacy of women on view in related English dramas and then offer a guess as to which traditions (if any) the Shrewsbury works most likely support.

Once the various English Easter dramas have noted the fact that the news of the Resurrection is given first and exclusively to women, these plays vary greatly in their treatment of the subsequent events. Some plays depict the passing of this news to the male disciples without any further reference to a special role for women; others expand the roles of the male apostles well beyond the biblical accounts; and still others refer to antifeminist traditions of women as untrustworthy, while seeming to agree with these traditions. ${ }^{71}$ For instance, in the Bodleian Resurrection, the men remain doubtful of the Resurrection until they see the evidence of the empty tomb (lines 704-29); in N-Town 36, Peter says to Mary Magdalene, "May I troste to at ze say?" (line 112); and, in the Trierer Osterspiel,

${ }^{68}$ Blamires, The Case for Women, p. 171. By using "profeminine" to discuss advocacy of women's preaching and other attitudes to women, Blamires avoids the confusion that a term such as "feminist" causes.

${ }^{69}$ See ibid., pp. 19-49; Coletti, Mary Magdalene and the Drama of the Saints, pp. 134-47; and Beverly Mayne Kienzle and Pamela J. Walker, eds., Women Preachers and Prophets through Two Millennia of Christianity (Berkeley, Calif., 1998).

${ }^{70}$ Medieval works cannot be "feminist" according to current understandings of the term, and, in any case, we do not see feminism as a monolithic set of attitudes. It is more accurate to write of "feminisms" than "feminism." See Susan Stanford Friedman, Mappings: Feminism and the Cultural Geographies of Encounter (Princeton, N.J., 1998), p. 221, and Rosi Braidotti, Nomadic Subjects: Embodiment and Sexual Difference in Contemporary Feminist Theory (New York, 1994), pp. 15558. Nevertheless medieval works often include advocacy of certain points of view that were often associated with women. See for instance the attitudes on view in Blamires, The Case for Women, pp. $10-12,64-65$, and $176-77$.

7 See Richard Bauckhaven, Gospel Women: Studies of the Named Women in the Gospels (London, 2002), pp. 257-310. For antifeminist tradition in the Middle Ages, see Blamires, ed., Woman Defamed and Woman Defended, pp. 99-197. 
Jesus, disguised as a gardener, accuses her of waiting by his tomb for her young lover (lines 84-87).

Of course, this well-known tradition of the men not believing the Marys' announcement of the Resurrection holds possibilities for irony, possibilities that Towneley 28 exercises most fully. Peter dismisses with scorn Mary Magdalene's news that she has seen Jesus: "Do way, woman, thou carpys wast! / It is som spirit or els som gast" (lines 7-8). The apostle Paul (appearing anachronistically) suggests that nobody could survive the crucifixion and "wherefor, woman, thou says wrang" (line 17). Peter then commodifies her speech and perhaps links it with Mary's former role as a prostitute when he associates her words with "fare" (line 25). Since both men address Mary pointedly as "woman," they would seem to think that her sex is a reason to doubt her word. ${ }^{72}$ But the antifeminist tradition that gives rise to these comments by the men is clearly being satirized here. Paul's appearance at this juncture would seem to occur because of his many writings concerning relations between men and women. ${ }^{73}$ In its satire Towneley 28 also makes use of its relationship to other pageants in its cycle. With the Marys' emotions at the crucifixion and burial fresh in the audience members' minds, Paul's accusation in Towneley 28 of women as inclined to hide their true feelings and present a false emotional front would ring hollow (lines 33-34). With his comparison of women to an attractive-looking apple that is rotten at the core (lines $38-43$ ), the play's audience is likely to reconsider the tradition of blaming women for all of men's ills from the act of disobedience (the eating of an apple) in Paradise on down. Paul's comparison is not apt when women know the essential truth and men do not. The ironies directed at men become most heavy-handed when Peter comments acidly that, before bedtime, Mary will be telling a different tale (lines 56-58) and when he attributes his despair, an emotional state that the women have already overcome (lines 65-96), partly to "drede of womans myght" (line 78). He irrationally blames a woman's challenge of him, on the night that Jesus was betrayed, for his decision to deny his Lord (lines 85-86)..$^{74}$

It would be irresponsible to claim that the Shrewsbury Fragments present a similarly profeminine attitude when so much of their content is mere conjecture. However, these plays certainly support the idea of the Easter message as originally "wymmen wordis" (Officium peregrinorum, lines 15-16), and, in the Officium Resurrectionis, there are further indications that these plays are not interested in supporting the medieval antifeminist tradition. For instance, the women assume a preaching role of their own volition. Also in the Shrewsbury drama, the three Marys usurp a typically male role within the liturgy. They say, "Alleluya schal be oure song" (line 30 ) when members of the clergy would usually initiate such praise in a liturgical context.

72 See Blamires, ed., Woman Defamed and Woman Defended, pp. 1, 7-8, 149, 205-9, and 26162 , for the many criticisms directed at women that concern intelligence, reason, and speech.

${ }^{73}$ Ibid., p. 36. De Boer notes that Paul seems to have begun the movement to omit the women from the Easter story; see Mary Magdalene (above, n. 38), p. 45.

${ }^{74}$ See the notes by Martin Stevens and A. C. Cawley concerning these antifeminist passages in The Towneley Plays, 2:618-19, and Coletti, "A Feminist Approach to the Corpus Christi Cycles," in Approaches to Teaching Medieval Drama, ed. Richard K. Emmerson, Approaches to Teaching World Literature 29 (New York, 1990), pp. 84-85. Cf. Chester 18, lines 60-71 and 73. 


\section{Mary Magdalene's New Language}

This moment of ecstatic praise leads us to our last and most speculative point concerning Mary Magdalene's preaching moment. Viewers of any liturgical drama within the context of church services throughout the year, or viewers of any entire cycle of mystery plays, would recognize that the Easter message means the redefinition of "history" and of many of the other foundational components of traditional discourse, through the evangelism and conversion of virtually the entire Roman Empire and then of the rest of western Europe and beyond. Mary's news is uniquely transformative. This quality of the Easter message might prompt one to wonder, then, whether it includes a fundamental change to language, perhaps even a "break from the dictatorship of patriarchal speech," as Elaine Showalter puts it. ${ }^{75}$ After all, this message comes first, directly from God through his angels, exclusively to women (the three Marys or Mary Magdalene individually) - a tradition that the Shrewsbury plays follow and even emphasize. Cleophas, in the Officium peregrinorum, expresses an intention to travel on the road to Emmaus (he and his companion will encounter the risen Christ on the way) and says, "By wymmen wordis wele wit may we / Crist is risen vp in gode aray; / For to oureself pe sothe say[d] he" (lines 15-17). Since many of the Easter dramas, whether German, Czech, French, or English, treat their scriptural sources with remarkable freedom (though the tradition of the first witnesses at the tomb being women would likely be the most influential tradition in the history of liturgical drama, and therefore relatively difficult to alter), the agreement among all medieval dramas on the point that the Resurrection was first communicated in "women's words" is telling.

Furthermore, the English Easter plays in general seem to take pains in order to mark separations between the words of women and men, as if the writers thought that habits of communication were different between the sexes. Such separations also would suggest differing treatment of women's and men's voices on the stage in England, even if all of the roles were taken by men. In the N-Town example, John says, "As women seyd, so haue we fownde" (36, line 151). Mary Magdalene remarks upon her "specyal speche" (line 2). The same play notes the difference in sound between male and female voices. Mary Salomé says, "Now lete us all thre fulfylle / De angelys wurde and Goddys wylle; / Lett us sey with voys wul shrylle" that Christ has risen (lines 87-93). Significantly, in this same N-Town cycle, Christ first offers the news of his Resurrection directly to his mother, an

${ }^{75}$ Elaine Showalter, "Feminist Criticism in the Wilderness," in Modern Criticism and Theory: A Reader, ed. David Lodge, rev. Nigel Wood, 2nd ed. (Harlow, Eng., 2000), p. 316. See also Jane Schaberg, The Resurrection of Mary Magdalene: Legends, Apocrypha, and the Christian Testament (New York, 2002), pp. 300-301. We realize that medieval people would not have viewed language as "patriarchal" in the same way as some people do now. We also realize that feminist criticism has largely moved on from Hélène Cixous's proposal that one can arrive at an exclusively feminine language through a sheer act of the will, the literary theory that probably best fits our argument at this stage. See her "The Laugh of the Medusa," trans. Keith Cohen and Paula Cohen, Signs 1 (1975-76), 87593. For more recent ideas concerning l'écriture féminine, see Friedman, Mappings, pp. 18 and 25, and Braidotti, Nomadic Subjects, pp. 21 and 129-33. 
action that, despite such radical changes to the scriptural narrative, continues the pattern of the Easter message being first conveyed to a feminine audience $(35$, lines 129-36). ${ }^{76}$ Elsewhere, the cycle seems to contrast the feminine point of view with the masculine. Just after the three Marys arrive at the sepulcher, the aggressively violent soldiers who crucified Jesus attempt to continue the "male version" of events by distorting the truth. Pilate bribes them so that "No talys xul be tolde" of the disappearance of Christ's body from the tomb (35, lines 286, 289, and 303).

This general pattern of separation between male and female voices in these plays suggests that, if the Marys were to keep the news of the Resurrection from the male apostles or tell it only to other women, then an exclusively feminine community and inheritance would be party to the Easter message. ${ }^{77}$ Moreover, an exclusively female language is also suggested by Mary Magdalene's tendency to preach in song. If nothing else, her use of the vernacular, and her transformation of a sacred chant into a secular form (the AAB form) in the Füssener Osterspiel and perhaps in Shrewsbury, marks a break with what has previously happened in the Easter drama and with (male) traditions more generally. Perhaps such a break indicates that the previously dominant modes of expression have been rendered inadequate by the extreme and unprecedented emotions that Mary has to express. In fact, the women at the tomb in the Easter plays often confess that what they are feeling is indescribable (Digby, line 1004; N-Town 37, lines 3 and 78-79; Chester 18, lines 420-33). In some ways, this expression of unprecedented emotions is an inheritance of a new language from the Virgin Mary, whose sorrow at the crucifixion is described in many works as both unprecedented and inherently feminine (N-Town 35, lines 129-32; Bodleian Burial, lines 637 and 662-69). ${ }^{78}$

${ }^{76}$ This modification of the scriptural narrative has a precedent in the Meditationes vitae Christi, conventionally attributed to the Franciscan author Johannes de Caulibus. The text was included in A. C. Peltier's edition of Bonaventure, Opera omnia, 12 (Paris, 1868), pp. 616-17; it is translated in Meditations on the Life of Christ, trans. Francis X. Taney, Sr., Anne Miller, and C. Mary StallingsTaney (Asheville, N.C., 2000), pp. 280-81.

77 The original Gospel accounts support the possibility of an exclusively female inheritance of the Easter message in several ways: Mark's Gospel probably ended originally at the point where the women tell no one what they have seen at the tomb because they are terrified (16.8). All of the Gospel accounts concur that the original Easter message, from angels or Jesus himself, was given only to women, not to the male apostles: even in John's Gospel, when Peter and John race to the tomb (an event unique to this Gospel), they find only material evidence that Jesus is not there. In Mark (16.11) and Luke (24.11), the male apostles do not believe the women's announcement of the Resurrection. For discussion, see Richard Atwood, Mary Magdalene in the New Testament Gospels and Early Tradition, European University Studies 23/457 (Bern, 1993), pp. 120-23.

${ }^{78}$ The manuscripts for the German plays that we consider include laments by the Virgin Mary. See nn. 44 and 45, above. There are works that conflate the Virgin's attributes with Mary Magdalene's. See Coletti, Mary Magdalene and the Drama of the Saints, pp. 151-54. More specifically, Marianne G. Briscoe explains how the expansion of the Virgin Mary's role and of certain of her speeches in medieval dramas is due to the influence of preaching. See "Preaching and Medieval English Drama," in Contexts for Early English Drama, ed. Briscoe and John C. Coldewey (Bloomington, Ind., 1989), pp. 162-67. Waters notes that, particularly for female preachers, prowess at the task of preaching is associated with the body, physical beauty, and contact with Christ's body. See Angels and Earthly Creatures, pp. 115-16. The last association in particular means that the Virgin Mary and Mary Magdalene would be potentially ideal preachers. 
A mirror image of the Virgin's mode of expression occurs when her three namesakes (or Mary Magdalene herself) reveal the news of the Resurrection and thus preach emotions just as profound and unprecedented as the Virgin's sufferingexcept that they preach overwhelming joy instead of sadness. In addition, a use of music as a kind of feminine language fits with several of the ecstatic visions of the thirteenth-century German mystic Mechtild of Hackeborn and with Julia Kristeva's theory of language. Kristeva employs terms from music when she describes the very bases of her theory. ${ }^{79}$

Finally, if the "lesson" that the three Marys present to the apostles is anything like the preaching of Mary Magdalene in the Füssener Osterspiel, certainly something like an exclusively feminine mode of expression through music would be on offer. In the German play, the apostles repeat again and again, "Dic nobis, Maria, quid vidisti in via" (Say to us, Mary, what you saw on the way), when they want her to continue the account of her encounter with the risen Christ (lines 139, 159, and 165; cf. the Bodleian Resurrection, p. 190). Their phrase, even though it is sung (it is part of the dramatization of "Victimae paschali laudes"), would seem to insist on the spoken word. It would seem to indicate an interest mainly in an account of the events that she experienced ("what you saw") as opposed to any interpretation of them. This phrase thus contrasts with the emotional tone and content, which increase in sophistication as she continues, of her musical exegesis. Her unprecedented emotions give rise to unprecedented expression and intellectual exercise through song, and the identically repeated phrase of the men suggests that they are left behind: excluded from her thoughts, weighed down by ordinary spoken language in the face of her virtuoso, heightened expression.

The wide distribution of similar programs of vernacular exegesis of Latin compositions concerning Mary Magdalene through both words and music among German, Czech, and English Easter dramas indicates a distinct and important phenomenon, particularly in its treatment of certain modes of expression and in its apparent advocacy of women's spiritual roles. It remains to explain how this phenomenon developed in England at the same time as it did on the Continent. Susan Rankin attributes the rise of separate Latin traditions concerning the Mary Magdalene scene in Easter ceremonies to the rapid growth of the cult of this saint in the eleventh century. ${ }^{80}$ We believe that further transmission of this didactic model in later examples of vernacular exegeses was almost certainly due to Franciscan influence. The program of musical and vernacular exegesis that we describe

\footnotetext{
${ }^{79}$ Mechtild, a very accomplished singer and instrumentalist, often communicates directly with God in her visions through music, which is presented as a kind of ideal communication. In one vision, Christ's heart conveys his message to her directly as she puts her ear to his breast and the heart "speaks" to her in rhythms like the beating of a drum. In another vision, a trumpet conveys messages to Mechtild by extending directly from God's body into her heart. See The Booke of Gostlye Grace of Mechtild of Hackeborn, ed. Theresa A. Halligan, Studies and Texts 46 (Toronto, 1979), 2.1, 1.2, and 1.68. Julia Kristeva's definition of the development of mother-child communication relies very much on the use of musical terms, which increase in conceptual complexity as her argument goes on: rhythm, tone, melody. See Kristeva, Desire in Language, ed. Leon S. Roudiez, trans. Thomas Gora, Alice Jardine, and Roudiez (New York, 1980), pp. 133-34.

${ }^{80}$ Rankin, “The Mary Magdalene Scene” (above, n. 9), pp. 228-29.
} 
corresponds well with the spiritual program of the Friars Minor, who developed missions with remarkable speed throughout Europe and England, beginning in the thirteenth century. ${ }^{81}$ Their influence upon preaching, popular piety, cultural material in general, ${ }^{82}$ and religious dramas with music in particular, was strong and pervasive. ${ }^{83}$ Moreover, the Franciscans' spiritual programs were often directed at women, as Katherine Jansen notes, ${ }^{84}$ and they modeled much of their spirituality on the figure of Mary Magdalene. ${ }^{85}$ Of course, a thorough study of these connections must wait for another occasion.

In general, evidence of music and stage directions in the Continental dramas seems to corroborate the perceptions of a few musicologists, such as Richard Rastall, who suggest that all texts in the Shrewsbury Fragments may have been sung. ${ }^{86}$ Rastall was unable to prove his supposition with analogues that portray musical readings of the drama. However, the evidence of notated music and stage directions in kindred dramas from the German lands and Bohemia supports his point of view and offers information that sheds new light on the role of music in the Shrewsbury Resurrection play. Recognition of a larger incidence of musical passages than one might expect reveals, moreover, the role of music in the vernacular exegesis and preaching of Mary Magdalene. The Shrewsbury Officium Resurrectionis integrates in its musical form rhetoric, narrative, and authority into

${ }^{81}$ By the beginning of the fourteenth century, the Franciscans had established approximately three hundred convents in the German lands, Poland, and Bohemia. Their first missions to these lands began in 1221. See John B. Freed, The Friars and German Society in the Thirteenth Century, Mediaeval Academy of America Publication 86 (Cambridge, Mass., 1977) pp. 21, 49, and appendix 1, tables 710. The Franciscans arrived in England in 1224. By 1255 they had established forty-nine convents there. See John Moorman, A History of the Franciscan Order (Oxford, 1968), p. 171. There would be even stronger suggestions of Franciscan influence upon the Shrewsbury Fragments if Anne of Bohemia's retinue included Franciscans when she arrived in England.

${ }^{82}$ See R. H. Robbins, "The Earliest Carols and the Franciscans," Modern Language Notes 3 (1938), 239-45; and David L. Jeffrey, The Early English Lyric and Franciscan Spirituality (Lincoln, Neb., 1975). For artworks from the German lands that depict Francis and Mary Magdalene in similar poses, see Elga Lanc, Die mittelalterlichen Wandmalereien in Wien und Niederösterreich, Corpus der mittelalterlichen Wandmalereien Österreichs 1 (Vienna, 1983), pls. 126 and 129. See Jansen, The Making of the Magdalen, pp. 93-97, for similar examples from Italian art (figs. 14, 16, and 17).

${ }^{83}$ See Walther Lipphardt, "Studien zur den Marienklagen: Marienklage und germanische Totenklage," Beitrage zur Geschichte der deutschen Sprache und Literatur 58 (1934), 408 and 426 . See also Peter V. Loewen, "Francis the Musician and the Mission of the Joculatores Domini in the Medieval German Lands," Franciscan Studies 60 (2002), 251-90; and David L. Jeffrey, "Franciscan Spirituality and the Rise of Early English Drama," Mosaic 7 (1975), 35. A. G. Little, in Franciscan History and Legend in English Mediaeval Art, British Society of Franciscan Studies 19 (Manchester, 1937), suggests direct connections between artworks and the performances of plays (p. 6).

${ }^{84}$ See Jansen, The Making of the Magdalen, p. 84, and John Coakley, "Gender and the Authority of the Friars: The Significance of Holy Women for Thirteenth-Century Franciscans and Dominicans," Church History 60 (1991), 445-60.

8.5 See Peter V. Loewen, "The Conversion of Mary Magdalene and the Musical Legacy of Franciscan Piety in the Early German Passion Plays," in Speculum sermonis: Interdisciplinary Reflections on the Medieval Sermon, ed. Georgiana Donavin, Cary Nederman, and Richard Utz, Disputatio 1 (Turnhout, 2004), pp. 235-59; Dixon, "Thys Body of Mary" (above, n. 65); and Susannah Milner, "Flesh and Food: The Function of Female Asceticism in the Digby Mary Magdalene," Philological Quarterly 73 (1994), 385-401.

${ }^{86}$ Rastall, Music (above, n. 42), p. 88. 
a new kind of preaching. Because of Mary's history, her preaching in this drama integrates male and female modes of expression into a highly individual preaching moment. In this musical context, her ecstatic statements also look forward to "an 'other meaning:' always in the process of weaving itself, of embracing itself with words, but also of getting rid of words in order not to become fixed, congealed in them." ${ }^{87}$

${ }^{87}$ Luce Iragaray, This Sex Which Is Not One, trans. Catherine Porter and Carolyn Blake (Ithaca, N.Y., 1985), p. 29.

Peter V. Loewen is Assistant Professor of Musicology at the Shepherd School of Music, Rice University, Houston, TX 77251-1892 (e-mail: puloewen@rice.edu). Robin Waugh is Associate Professor of English at Wilfrid Laurier University, 75 University Avenue West, Waterloo, ON N2L 3C5, Canada (e-mail: rwaugh@wlu.ca). 


\section{APPENDIX}

The Appendix includes all of the lines in sequence from the Shrewsbury Officium Resurrectionis. We have reorganized the texts in the other dramas so as to focus on the parallels that exist between them and the Shrewsbury text. Stage directions are represented in boldface. Latin and vernacular texts from the Trierer Osterspiel, Füssener Osterspiel, and the Prague Ordo trium personarum are given by incipits except where there are parallels with the Shrewsbury text. Passages that have similar content are printed in full. All lines of Latin text in the Trierer Osterspiel, Füssener Osterspiel, and the Prague Ordo trium personarum are set to music unless indicated by a dagger $(\dagger)$; a double dagger $(\ddagger)$ indicates a vernacular text with music.

\section{SOURCES:}

Except where noted below, editions of the musical examples are by Peter V. Loewen.

Shrewsbury Officium Resurrectionis: (Text) Norman Davis, ed., Non-Cycle Plays and Fragments, Early English Text Society, S.S., 1 (London, 1970), pp. 3-4. (Music) Based on Richard Rastall, Music in Early English Religious Drama, 1: The Heaven Singing (Woodbridge, Eng., 1996), pp. 102-4.

Trierer Osterspiel: Ursula Hennig, in Ursula Hennig and Andreas Traub, eds., Trierer Marienklage und Osterspiel, Codex 1973/63 der Stadtbibliotbek Trier, Litterae 91 (Göppingen, 1990), pp. 52-66. The music is meticulously notated with Messine neumes on five-line staves with F- and C-clefs.

Füssener Osterspiel: Dietrich Schmidtke, ed., Das Füssener Osterspiel und die Füssener Marienklage, Universitätsbibliothek Augsburg (ehemals: Harburg), Cod. II, 1, 4 , 62, Litterae 69 (Göppingen, 1983), pp. 10-15. The Füssen edition differs from the other editions in its use of italics, which we have removed for the sake of consistency. The music is notated in a cursory hand in what Walther Lipphardt had identified as "cursive Gothic chant notation in 'Häkchenform' on four-line staves with F- and C-clefs" (cited by Schmidtke, p. 8). Ordo trium personarum: Jan Máchal, ed., Staročeské skladby dramatické, piovodu liturgického, Rozpravy České Akademie Císaře Františka Josefa pro Vědy, Slovesnost a Umění 3/23 (Prague, 1908), pp. 98-105. (We have replaced Máchal's line numbers with our own continuous numbering.) The music is meticulously notated with Messine neumes on fourand five-line staves with C-clefs. 
Shrewsbury Officium Resurrectionis Shrewsbury School MS VI (c. 1430 ), fols. $38 \mathrm{r}-42 \mathrm{v}$

Hic incipit Officium Resurrectionis in die Pasche.
Trierer Osterspiel

Trier, Stadtbibliothek, MS 1973/63

(first half of the fifteenth century), pp. 19-30
Incipit Ludus de nocte pasche de tribus Mariis vel tres Marie
Prima Maria cantat

Heu nobis internas mentes.

Iam percuso heu pastore.

Sed eamus et ad eius properemus. 
Füssener Osterspiel

Augsburg, Universitätsbibliothek, MS II.1.4.62

(first half of the fifteenth century), fols. $137 \mathrm{r}-141 \mathrm{r}$

Silete silete

Nu swigent, lieben lúteł

$\mathrm{Tu}(\mathrm{n}) \mathrm{c}$ p(rim)a Maria exit $\mathrm{d}(\mathrm{e})$ choro ac cantat:

Jhesu, $\mathrm{n}(\mathrm{ost})$ ra rede(m)pcio

Rithm(us):

Got Ih(es)us, d(er) weit ein lósser

(1)

Tu(nc) (secund)a Mari(a) cantat:

Que te vincit clem(en)cia
Ordo trium personarum

Prague, University Library, MS I.B.12

(1384), fols. $135 \mathrm{v}-137 \mathrm{v}$
Dum transisset.

Prima persona cantet.

Omnipotens pater altissime 4

Hospodyne wsemohuczy

Secunda persona cantet.

Amisimus enim solacium

Stratyly sme mystra sweho

(Tercia persona cantet.)

Sed eamus vngentum emere $\quad 20$

Pospyesme masty kupyty

Quo finito dicant omnes rykmum istum et sequ.

Ach, kaku my zalost gmane.

Quo finito prima persona procedat.

Heu, nobis internas mentes

Quo finito dicat ricmum.

Horze nam neboham, kaczy smutczy 36

Jam percusso ceu pastore $\quad 44$

Quo finito dic. ricm.

Apostoly mystra sweho $\quad 50$

Sed eamus et ad eius properemus $\quad 54$ 
(See line 15 below for parallel passage.)

(See line 23 below for parallel passage.)
Prima Maria dicat rickmum Owe owe

Owe owe der vyll grymmygen hant, 10 Dye aller werlde heylant

An das cruycze hayt ghehangen.

Her hayt dorch den menczschen die martylge entphangen.

Owe ir judden wylch eyn groeß mort, Wye mychel vnd vngehort.

Vorsteynt vwer herczen synt,

Ir hayt gecruzyget dye muetter als dat kynt.

Secunda Maria dicit rickmum

Owe, we gar irlychen is steyt

\section{Tercia Maria dicit rickmum}

Susteren, wyr wollen vor dem dage

Et immediate procedentes ad sepulchrum simul cantando antiphonam Sed eamus

Sed eamus ungentum emere

Quis reuoluet nobis ab hostio lapidem

Tercia Maria dicit rickmum

Wer wyl vns van dyßem grabe

Tunc angeli cantant. Et primus angelus dicit rickmum

Quem queritis, o tremule mulieres

[W]enen sucht ir drij frauwen

Marie simul cantant antiphonam

Ihesum

Jhesum nazarenum crucifixum

Tercia Maria dicit rickmum.

Wyr suechen Jhesum vnseren troest 
Rithm(us):

Jesus, din geit dich bezwungen haut, wan du vz $\mathrm{i}(\mathrm{n})$ sinden nit $\mathrm{v}(\mathrm{er})$ lost, du werdest gehangen andez crŭczze ast,

daz du trůgest vns(ere) $n$ sủnden last

vn(d) laidest den biter tód,

daz du vz nemest von der helle not.

Tercia Ma(r)ia ca(n)tat:

Jpsa te cogat pietas

Rithm(us) (com)m(un)is:

Din milte die zwinget dich

Tu(n)c (con)gregat(ur) an(te) sepulch(rum) (et) ca(n)tant o(mn)es: Qvis reuoluet nob(is) lapide(m)

P(ri)ma Maria cantat:

Wer hebt vz den stein hin tan

$\mathrm{Tu}(\mathbf{n}) \mathbf{c}$ ang(e)li canta(n)t:

Que(m) q(ue)ritis, o tremule $\mathrm{m}(\mathrm{u}) \mathrm{l}$ (ie)res

\section{Rithm(us):}

Wen sucht ir betrübten frawe(n)

Tu(n)c Maria cantat: "Jh(esu)m Naz(are)nu(m)." (Secund)a Maria cantat:

Jhesu(m) Nazarenu(m) crucifixu(m) q(ue)r(i)mus.

Rithm(us):

Von Nazaret Ih(esu)m Crist
Quo finito ricmum subiungat.

Poydem skuoro $k$ gyeho hrobu, Drahe masty nessucz ssebu, Yakz ssme gyey zywa mylowaly, Myluyme gyei mrtwa sucze.

Hoc finito omnes persone cantent:

Quis reuolluet nobis ab hostio lapidem

Quo finito ricmum subiungant.

Ktho nam ten kamen otlozy

Hoc finito statim angelus in sepulcro cantet.

Quem queritis, o tremule mulieres

Quo finito dicant ricmum omnes simul:

Koho wy, panye, hledate w tom hrobye

Persone cantent.

Jesum nazarenum crucifixum querimus.

Quo finito ricmum subiungant.

48 My hledamy tworczye ssweho 
Angeli simul cantant

Non est hic quem queritis

Secundus angelus dicit rickmum

Hye en yst nycht hy

Et tunc angeli simul cantant Venite et videte locum

Venite et videte locum

[S]ehyt yn das grab

Tunc Marie recedendo simul cantant Ad monumentum

Ad monumentum venimus gementes

[W] yr waren gegangen zue dem grabe

Tunc procedunt et cantat prima recedens versum

Ihesu nostra redemptiof

Deinde secunda secundum versum Que te vicit†

Deinde tercia vltimum versum vlterius procedendo cantando

Cum venissem vngere mortuum 
Tunc ang(e)li canta(n)t:

Non e(st) hic q(uem) q(ue)rit(is)

Rithm(us):

Er ist nit hie, den ir da welt

Tunc $a(n) g(e) l i$ tolla(n)t sodona (!) et po(s)it(us)."

Venite et videte locu(m)

A(n)g(e)li ca(n)tant. Rithm(us):

Nu kưme(n)t h(er) ir betrwbbten frawen

(The sequence of lines continues below, line 65.$)$

(Inserted from later in the drama)

$\mathrm{Tu}(\mathrm{n}) \mathrm{c}$ ean(n)t desepulch(ro) (et) canta(nt) o(mn)es Mar(ie) si(mu)l: "Admonim(entum) venimus."

Ad mo(ni)m(en)tu(m) ve(n)i(mus) gem(en)tes

Rithmus. Tres Marie cantant: Zů dem grab wir kůmen cantant: "Venite et videte locu(m) vbi

Angelus cantet.

Non est hic, quem queritis

Quo finito ricmum subiungat.

Koho wy, panye hledate

Quo finito angeli statim cantent:

"Venite et videte" et persone in sc.

Mariam magdalenam se inclinando respiciant in sepulcrum et sitam. Tum tercia persona dicat ricmum ad primam et secundam personam.

Nuz wy, ssesstryczye, prycz dyeta

Et hoc finito prima et secunda persona transeant successive retro altare cantantes ant.

Ad monumentum venimus gementes

Quo finito tercia persona cantet paulatim.

Maria cantat:

Cum venissem vng(re) mortuu(m)

Cum venissem vngere mortuum

Jch kủm gega(ng)en sůchen den lieb(e)n h(er)en minł

Kdyz byech przyssla leczyty mrtweho

Quo finito cantet ricmum.

En lapis est vere depositus

\section{Eodem modo.}

Owa, kamen, gyenz byeze na hrob polozen 
Was yst nu myn leben $\ddagger$

Owe owe myr armen $\neq$

Saluator in specie ortulani cantat

Mulier, quid ploras, quem queris?

\section{Et dicit cum hoc rickmum}

Jst dyt gueder frauwen recht

Maria cantat Domine si tu sustulisti eum etc.

Domine, si tu sustulisti eum, dicito michi,

et vbi posuisti eum, et ego eum tollam.

\section{Et dicit rickmum}

[G]ued man, ruche, wez ich wartten

Salvator respondit rigmatice cantando Gued wyff, sueche yn ane mynen haß

Deinde Maria iterum cantat rigmatice Dolor

Dolor crescit, tremunt precordia

III. Maria.

Heu! Redemcio Israel,

Heu, heu, heu redemtio Israel, ut quid mortem sustinuit. 
(The sequence of lines continues below, line 92.)

$\mathrm{Tu}(\mathrm{n}) \mathrm{c}$ apariat do(min)ica $\mathrm{p}(\mathrm{er})$ sona (et) cantat q(uod) sequit(u)r: "Mulier, quit ploras?"

Mvlier, quit ploras? Que(m) q(ue)ris? 114

Rithm(us):

Maria, wen suchest du?

Inde $\operatorname{Mar}(\mathrm{i}) \mathbf{a} \operatorname{Mag}(\mathrm{da})$ lena cantat hoc:

Quia tollerunt (!) d(omi)n(u)m meu $(\mathrm{m})$

et nescio, vbi possueru(n)t eu(m).

\section{Rithm(us):}

Mein h(er) Ihe(sus) Crist ist auf gehebt

(The sequence of lines continues below, line 124.)

(Terci)a Maria ca(n)tat:

Dolor crescit, tremu(n)t $\mathrm{p}(\mathrm{re})$ cordya

Durch got ir frawen ir helfen clagen mir mein lait!

(The sequence of lines continues below, line 100.)

$\mathrm{Tu}(\mathbf{n}) \mathrm{c}$ Marie it(erum) $\mathrm{p}$ (ro)pin(ant)es sepulch(ro) canta(n)t omnes simul q(uod) sequ(i)t(ur):

Heu, heu rede(m)ptor Israhel ut q(uid) mo(r)te(m) sustinisti (!).
Powyez, cztna zeno, czo hledas

Postea dicat ricmum.

Cztny muzy, racz powyedyety

(End of insertion)

(The sequence of lines continues below, line 145.)

Quo finito cantet.

Dolor crescit, tremunt precordia

The sequence of lines continues

His finitis ihesus exeat indutus et cantet ant. "Mulier."

Maria cantet

Domine, si tu sustulisti eum

\section{Eodem modo cantet.}

Bolest roste memu frdczy wtrobe

Cantet heu redempcio.

Heu redempcio israhel, ut qui nasci voluit.

Heu redempcio israhel, ut qui pati voluit.

Heu redempcio israhel, ut qui mortem sustinuit paciens. 
[II. Maria.]

... payne.

III. Maria.

Allas! he pat men wend schuld by All Israel, bothe knyght and knaue, Why suffred he so forto dy, Sithe he may all sekenes saue?

Heu! cur ligno fixus clauis Fuit doctor tam suauis? Heu! cur fuit ille natus Qui perfodit eius latus?

[II. Maria.] ... is oght.
Myn leyd dat wysset, myn hercze trurych yst, nu myn lyebe meyster ghestorben yst, Der mych van sewen dufellen machte fry, dye myr alles stedys woenten nahe by.

Owe owe owe myn heyl, myn troest, myn got, warumbe lydestu den bitterren doet? $\neq$

(The sequence of lines continues below, line 110.)

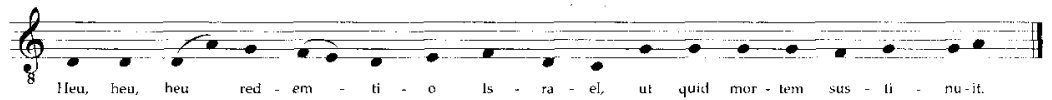

1.a. Trier.

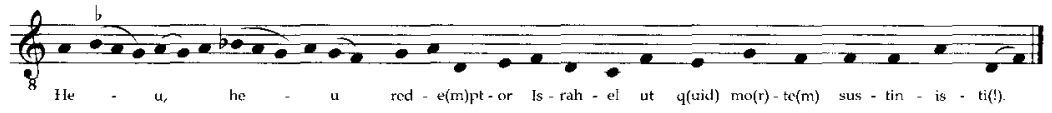

1.c. Füssen. 
O we, o we, got Jh(esu)s erzage dich den, die mit iam(er) nủ sủchen dich!†

\section{Quo finito eadem nota cantet in} vulgari.

Awech, mnye hubenyczy,

Yenz ssye chtyel narodyty.

Awech, mnye hubenyczy,

Yenz trpyety raczyl za ny.

Awech, mnye hubenyczy

ienz chtyel vmrzyety za ny pokornye.
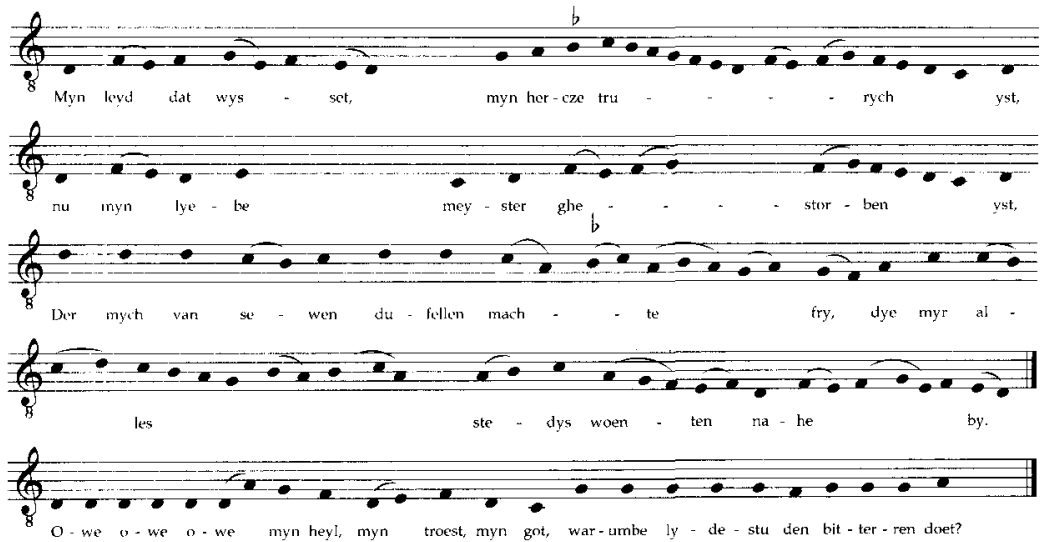

1.b. Trier. B-flats derive from the notation of "Owe der mere" (line 77), which has essentially the same melody as "Myn lyed dat wysset."

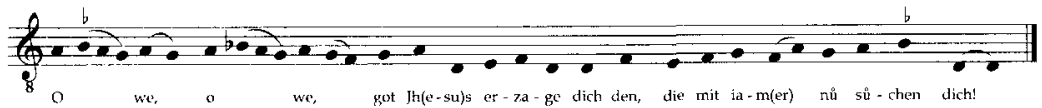

1.d. Füssen. 

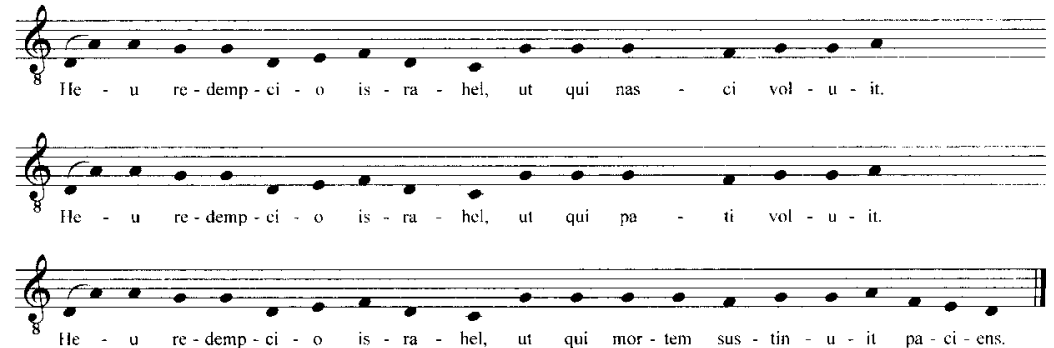

1.e. Prague.

Shrewsbury (continued)

\section{Maria.}

Allas, pat we suche bale schuld bide Pat sodayn sight so forto see, Pe best techer in world wide With nayles be tacched to a tre!

Allas, pat euer so schuld betyde, Or pat so bold mon born schuld be For to assay oure Saueour side And open hit withoute pité.
Trier (continued)

(Inserted from above)

Prima Maria dicat rickmum Owe owe

Owe owe der vyll grymmygen hant,

Dye aller werlde heylant

15 An das cruycze hayt ghehangen.

Her hayt dorch den menczschen die martylge entphangen.

Owe ir judden wylch eyn groeß mort, Wye mychel und vngehort. Vorsteynt vwer herczen synt, kynt. 


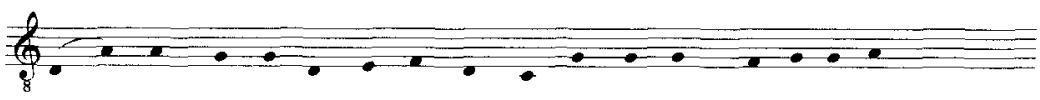

A - wech, mnye hu - be - ny - cay, Yenz ssye chtyel na - ro - dy - ty.

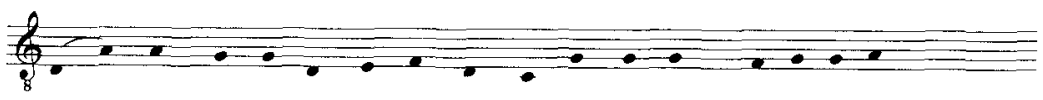

A - wech, mnye hu - be - ny - ezy, Yenz tr - pye - ty ra - czyl za ny

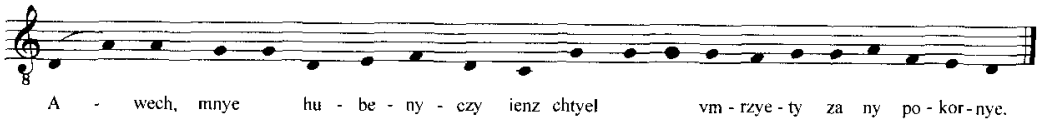

1.f. Prague (musical setting realized according to stage direction before line 129).

Füssen (continued)

Tres Marie canta(n)t si(mu)l:

O we, o we,

o we, wir a(r)men frawen,

da wir kument schawe(n), got vn(d) aller welt ein trost,

d(er) us vo(n) de(n) tot erlost.

Sy hete( $n)$ in $v(e r)$ borg(e)n

vnd(er) eine $(m)$ stain,

do vo(n) sye vir insorg(e)n.

Sy fvrten(n) in als eine( $\mathrm{n})$ diep, die iuden, den Judas v(er)reit, dez us sine(m) lip geng wasser vn(d) plüt.

Owe, wie ve daz mine(m) h(er)zen tůt!

Sy heten in gefangen,

zwischnu(n)t zwen schager

gehangen. $\neq$

\section{(The sequence of lines continues} above, line 114.)
Prague (continued)

(Inserted from above)

Quo finito ricmum subiungat.

100

Poydem skuoro k gyeho hrobu,

Drahe masty nessucz ssebu,

Yakz ssme gyey zywa mylowaly,

Myluyme gyei mrtwa sucze.
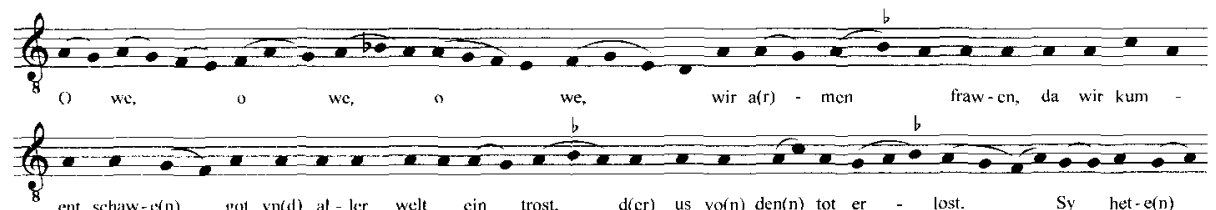

8 ent schaw-e(n), got vn(d) at-ler welt cin trost, d(er) us vo(n) den(n) tot er - lost. Sy het-e(n)
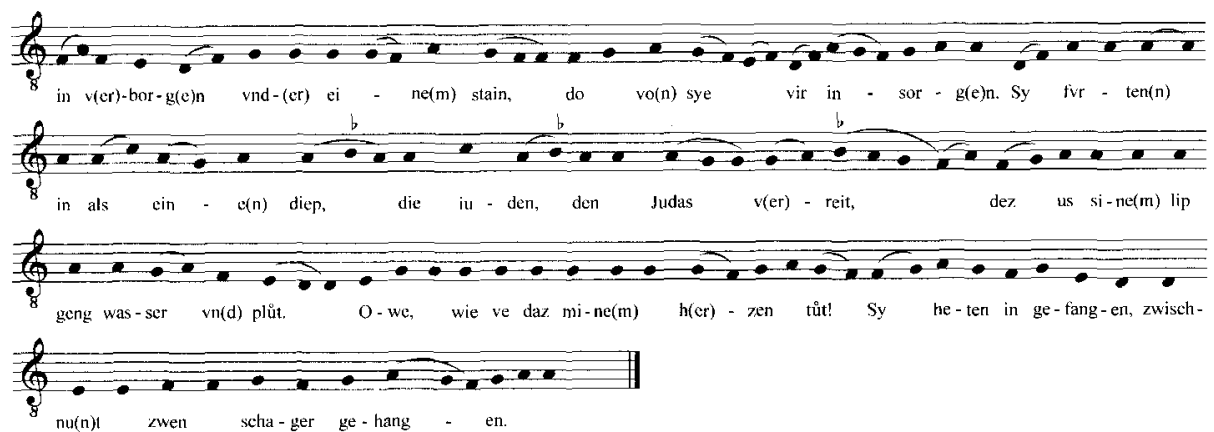

2. Füssen. 


\section{[All Three.]}

Iam iam, ecce, iam properemus ad tumulum,

Vnguentes Dilecti corpus sanctissimum!

\section{Et appropiantes sepulcro cantent:}

O Deus, quis reuoluet nobis lapidem $\mathrm{Ab}$ hostio monumenti?

\section{[II Maria.]}

... him leid.

\section{Maria.}

He pat pus kyndely vs has kend Vnto be hole where he was hid,

Sum socoure sone he wil vs send, At help to lift away pis lid.

\section{Maria.}

Alleluya schal be oure song,

Sithen Crist, oure Lord, by angellus steuen,

Schewus him as mon here vs among And is Goddis Son, heghest in heuen.
(Inserted from above)

... simul cantando ... (See directions before line 32, above.)

Quis reuoluet nobis ab hostio lapidem, quem tegere sanctum cernimus sepulchrum?

Tercia Maria dicit rickmum

Wer wyl vns van dyßem grabe

Den steyn heben her abe?

Das got dar vmb sy syn loen

Vnde helffe em in den obersten troen.
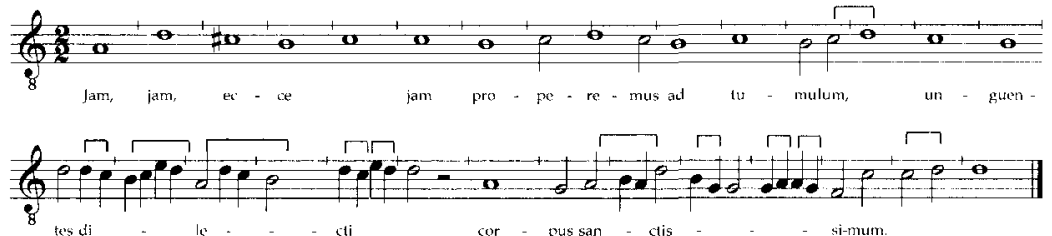

3.a. Shrewsbury. 
(Inserted from above)

$\mathrm{Tu}(\mathbf{n}) \mathrm{c}$ (con)gregat(ur) an(te) sepulch(rum) (et) ca(n)tant o(mn)es: Qvis reuoluet nob(is) lapide(m) abhostio, que $(m)$ ta(n)ge(re) sanctu(m) cernim(us) sepulch(rum)?

P(ri)ma maria cantat:

Wer hebt vz den stein hin tan, den wir suchend sechen uf dem grab ston, $\mathrm{d}(\mathrm{er}) \mathrm{daz}$ grab beschslossen hat? So wirt vns(er) sarge(n) rat.
(Inserted from above)

Hoc finito omnes persone cantent:

Quis reuolluet nobis ab hostio lapidem, quem tegere sanctum cernimus sepulcrum?

Quo finito ricmum subiungant.

Ktho nam ten kamen otlozy,
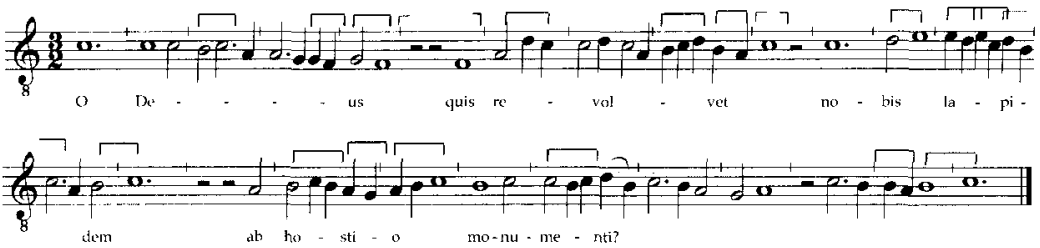

3.b. Shrewsbury.

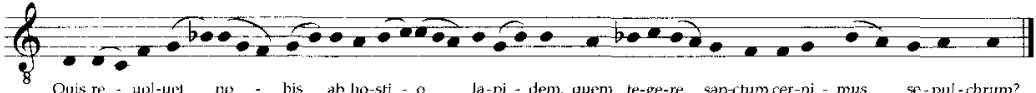

3.c. Trier.

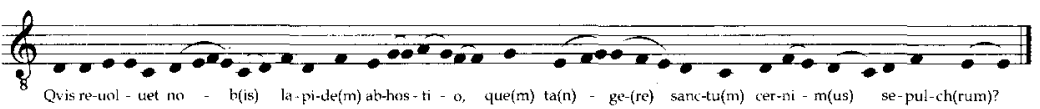

3.d. Füssen.

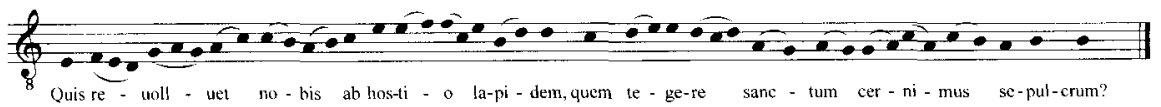

3.e. Prague. 
(Continued from above)

Tunc accedit Saluator et cantat Maria ut sequitur cum rickmo

Maria!

et dicit rickmum

[M]aria, du salt dych vorsynnen

Tunc Maria cantat immediate

Rabi, quod dicitur magister.

Et dicit

Ich horen dyne stymme, here.

Et tunc Saluator iterum cantat Maria cum rickmo vt prius supra

Maria respondit iterum Rabi cantans cum rickmo ut prius Ich hoere

Item post hoc vlterius cantat maria Tibi gloria in secula.

Et dicit rickmum Ich hore here dyne stymme ut supra

Post hoc saluator immediate cantat Prima quidem

Prima quidem suffragia

Maria cantat

Sancte Deus!

Et dicit rickmum

Here vader vnde son

Deinde Saluator vltra cantat stando 〈quod〉 sequitur

Hec priori dissimilis

Maria cantat

Sancte fortis. $\dagger$

dicendo rickmum Here vader vnde son 


(Continued from above)
Do(min)ica p(er)sona cantat ad
Mariam Magdalenam q(uod)
seq(uitur):
Maria, Maria, Maria!

(Maria Magdalena:)

Rabi, q(uod) di(citur) margist(er).

Rith(mus):

Jch waicz nu wol daz du ez bist
(Continued from above)

(See above for intervening text, line 135.)

Hoc finito Ihesus cantet.

Maria!

Maria cantet.

125 Rabbi!

Ihesus cantet:

Prima quidem suffragia

Maria cantet.

Sancte deus!

Ihesus cantet.

Hec priori dissimilis

Maria cadens ad pedes.

Sancte fortis! 
Deinde Saluator cantat ut sequitur

Ergo noli me tangere

Ergo noli me tangere

Et dicit cum hoc rickmum

[M]aria, du sald mych nyet angryffen 135

Maria cantat Sancte et immortalis

Sancte et immortalis

Et dicit rickmum

$[\mathrm{H}]$ eyliger here, godes son

Et tunc saluator recedit. Maria cantat $\langle$ quod $\rangle$ sequitur

Vere vidi dominum viuere

Ich sach werlychen leben den herren mynł

\section{Et dicit rickmum}

$[\mathrm{N}] v$ myrcket alle crystenlude

(Inserted from incipit below)

[II. Maria.]

Et cum hoc incipiet cantor 
Tu(n)c do(min)ica p(er)sona cantat q(uod) sequit(ur):

Noli me tange(re)

Rith(mus):

Maria, du solt mich nit rủen an

$\mathrm{Tu}(\mathbf{n}) \mathrm{c}$ cantat Maria q(uod) sequitur:

Sancte deus. Sancte fortis

Rithm(us). M(ar)ia Magtd(alena):

Du hailger got

Tu(n)c chor(us) cantat: "Victime paschali" vsque: "Dic nob(is) Maria." [Victimae paschali laudes]

$\operatorname{Tu}(\mathbf{n}) \mathfrak{c}$ Peitr(us) (et) Joh(ann)es ve(n)ia(n)t et canta(n)t:

Dic nob(is), Mariat

Rithm(us) dicat Johannes quot sequit(ur):

Sag us Maria, raines wibp

$\operatorname{Tu}(\mathbf{n}) \mathrm{c}$ Mar(r)ia ca(n)tat:

Sepulchru(m) v(ere) viue(n)t(is) $\dagger$

Rithmus. Cantat q(uod) seq(uitur): Jch hon gesche(ge)n daz heilgk grab

$\mathrm{Tu}(\mathbf{n}) \mathbf{c}$ it(eru)m Petr(us) (et)

Joh(ann)es cantant:

Dic nob(is), Ma(r)ia†
(Ihesus).

Ergo noli me tangere

Quo finito ihesus dicat ricmum.

Maria, nerod plakaty

(Maria).

Sancte misericors saluator

Quo finito ihesus recedit cantando.

Ascendo ad patrem

Hoc finito Maria cantet.

Vere vidi dominum viuere

Eadem nota in vulgari.

Zagyste ssem wydyela hospodyna $\quad 175$

(Hoc finito cantet: Victime paschali la).

Quo finito cantet per ordinem

"Victime paschali" usque "Dic nobis

Maria."

Interim Petrus et Iohannes currant ad eam et dicant: "Dic nobis, Maria, quid vidisti in via."

Maria cantet "Sepulcrum christi

viuentis" usque "Surrexit christus." 181 


\section{Maria.}

Surrexit Christus, spes nostra;

Precedet vos in Galileam.

Crist is rysen, wittenes we

By tokenes pat we haue sen pis morn! Oure hope, oure help, oure hele, is he, And hase bene best, sithe we were born!

If we wil seke him for to se, Lettes noght pis lesson be forlorn; But gose euen vnto Galileepere schal ze fynd him zow beforn!

\section{Et dicit rickmum}

$[\mathrm{N}] v$ myrcket alle crystenlude,

Dye vff dyssem dage hude

Vmb genade hy vorsammet stayn, Ich verkundygen uch genczlichen an allen waen,

Das vff erstanden yst vnßer troest,

Der alle de werlde ouch hayt erloest.

Ich mueß daz werlych jeheen,

Das ich yn liebennych hayn gheseheen,

Der dae leyt vor alle sunder den bytteren doet

Vnd mannge angest vnd groeße noet Jemerlychen hayt geleden,

Das her vns muchte gefreden

Myd dem ewygen vader syn.

Her hayt vorrycht dye ewyge pyn

Vnd wyl vns nu dye ewyghe freude geben

In dem ewyge $\langle\mathrm{n}\rangle$ leben,

Dye her vns gar dure ghekaufft hayt

Myd syme roeßen varben blode roet.

Des keyn menczsche vmmer vergessen sal,

Is sal eme dancken ane zal.

Hude van des dodes banden

Ist vnßer here froelychen vff erstanden.

Myd deme sollen wry alle froelychen syn

Vnd laessen alle truren lygen.

Et cum hoc incipiet cantor sequentiam Victime paschali etc. 
Tunc Maria cantat [uel ang(e)li (!)]:

Angelicus test(is) $\dagger$

Rithmus se(quitur):

Jch hon gesche(ge)n den engelich(e)n man

Jt(eru)m Pet(rus) et Joh(ann)es cantant:

Dic nobis, Mariat

Quo finito Petrus et Iohannes dicant

"Dic nobis Maria" ut s.

$\mathrm{Tu}(\mathrm{n}) \mathbf{c} \operatorname{Mar}(\mathrm{r})$ ia cantat Surrexit (Cristus) spes mea: $\mathrm{p}(\mathrm{re}) \mathrm{ce}(\mathrm{det})$ [suos in Galilaea]. $†$

Maria respondeat:

Rithm(us):

Crist mein trost ist er standen vo(n) dez tottes banden vnd heiczzen sin iung(er) kůnden vnd Petro beswnder, da er in Galilea wirt gefunden.

$\mathrm{Tu}(\mathbf{n}) \mathrm{c}$ Petrus (et) Johannes cantant q(uod) seq(uitur):

Cvrrebant duo simul et ille alius $†$
Chorus cantet: "Credendum est." $†$

Demum sequitur: "Te deum

laudamus. ..."† 